Article

\title{
The Biogeography of Great Salt Lake Halophilic Archaea: Testing the Hypothesis of Avian Mechanical Carriers
}

\author{
Bex L. Kemp ${ }^{\dagger}$, Erin M. Tabish ${ }^{\dagger}$, Adam J. Wolford ${ }^{\dagger}$, Daniel L. Jones, Jaimi K. Butler and \\ Bonnie K. Baxter*D
}

Great Salt Lake Institute, Westminster College, 1840 South 1300 East, Salt Lake City, UT 84105, USA; bkemp@westminstercollege.edu (B.L.K.); erintabish@gmail.com (E.M.T.); adam.wolford@gmail.com (A.J.W.); dan.jones@hsc.utah.edu (D.L.J.); jbutler@westminstercollege.edu (J.K.B.)

* Correspondence: bbaxter@westminstercollege.edu; Tel.: +1-801-832-2345

+ Authors contributed equally.

Received: 1 November 2018; Accepted: 20 November 2018; Published: 27 November 2018

\begin{abstract}
Halophilic archaea inhabit hypersaline ecosystems globally, and genetically similar strains have been found in locales that are geographically isolated from one another. We sought to test the hypothesis that small salt crystals harboring halophilic archaea could be carried on bird feathers and that bird migration is a driving force of these distributions. In this study, we discovered that the American White Pelicans (AWPE) at Great Salt Lake soak in the hypersaline brine and accumulate salt crystals (halite) on their feathers. We cultured halophilic archaea from AWPE feathers and halite crystals. The microorganisms isolated from the lakeshore crystals were restricted to two genera: Halorubrum and Haloarcula, however, archaea from the feathers were strictly Haloarcula. We compared partial DNA sequence of the 16S rRNA gene from our cultivars with that of similar strains in the GenBank database. To understand the biogeography of genetically similar halophilic archaea, we studied the geographical locations of the sampling sites of the closest-matched species. An analysis of the environmental factors of each site pointed to salinity as the most important factor for selection. The geography of the sites was consistent with the location of the sub-tropical jet stream where birds typically migrate, supporting the avian dispersal hypothesis.
\end{abstract}

Keywords: Great Salt Lake; halophiles; haloarchaea; microbial biogeography; American White Pelican; avian carriers

\section{Introduction}

Halophilic archaea dominate the Earth's many hypersaline environments such as salt lakes, underground salt deposits, and solar salterns [1-5]. These microorganisms live at low water activity and can tolerate sodium chloride brine at saturation, even in fluid inclusions of salt (halite) crystals [6]. In fact, several studies point to the possibility of the survival of halophiles over geologic time scales in halite [2,7-21]. Not only can halophilic archaeal species survive inside halite crystals, they also can likely survive space conditions: Halorubrum chaoviator thrived in culture following space exposure experiments [22-24]. One key to their ability to persist in extreme conditions is that haloarchaea are polyextremophiles, tolerating not only salinity, but also desiccation and high levels of ultraviolet (UV) irradiation [25]. Indeed, haloarchaea have a suite of genetic capacities that include the ability to survive high osmotic stress [26,27] as well as robust DNA repair and photoprotection mechanisms [25,28-30].

Cultivation approaches have identified members of the class Halobacteria, which are characterized by containing carotenoid-pigments and being aerobic or facultative anaerobic and are represented by 
at least 47 genera and 165 species [31]. Two genera, Halorubrum and Haloarcula, are overrepresented in culture studies [32,33] and each has a significant number of species [4,31]. Halorubrum [34] has 25 species known at this time [31] and a wide distribution around the globe in modern and ancient salt deposits or hypersaline aquatic environments [1,3,17,28,35-38]. Halorubrum is considered the most highly represented archaeal genus in many salterns after Haloquadratum [39]. In molecular analyses of $16 \mathrm{~S}$ rRNA genes in saltern crystallizer ponds, Halorubrum makes up $4 \%$ to $17 \%$ of the microbial population $[3,38]$. A spatial study of Halorubrum species surveying salt mines and ponds in China discovered 29 strains of with nineteen lineages [37]. Halorubrum species, like other halophilic archaea, have high rates of recombination and horizontal gene transfer, and it is clear that these mechanisms can increase genetic diversity within the genus [35,40,41]. As a result, Halorubrum may represent the largest number of species grouping within the family of Halobacteriace [31,37]. For example, Haloarcula marismortui was discovered in the Dead Sea [42], Haloarcula japonica was isolated from a Japanese saltern [43], and Haloarcula hispanica was cultured from a Spanish saltern [44]. The genomes of both Halorubrum and Haloarcula populations, even in a single setting, can be altered rapidly through gene transfer or recombination events [41].

Halorubrum and Haloarcula species, among other haloarchaea, reside in the salt-saturated regions of Great Salt Lake (GSL), a natural hypersaline terminal lake in Utah [5]. These GSL haloarchaea remain relatively stable over time. In addition, they survive the fluctuation of temperature and salinity in GSL [45], desiccation inside halite crystals [28], and even desiccation in brine shrimp cysts [46]. A GSL Haloarcula strain was shown to adjust gene expression in response to stress [45], and a GSL Halorubrum strain was shown to be highly resistant to desiccation and UV light [28]. These observations suggest mechanisms that assist survival over time under sub-optimal growth conditions in the environment of GSL.

GSL is the largest lake in the western United States and the fourth largest meromictic lake in the world [47]. Thus, this enormous inland sea is a critical stop on the Pacific flyway; GSL hosts an estimated ten million water birds (around 250 species), making the lake the most important shorebird site in North America [48-52]. The avian population spends time in the haloarchaea-enriched waters as many birds eat the invertebrates, namely brine shrimp (Artemia franciscana) and brine flies and their larvae (Ephydra spp.) [53-57]. Other avian visitors do not eat from the lake but instead find GSL gives them solace from predators. This is the case with the American White Pelicans (Pelecanus erythrorhynchos; AWPE) on Gunnison Island in the north arm [50], which is isolated by a railroad causeway (Figure 1). Here the waters are rich with halophilic archaea [5].

As described above with the examples of Halorubrum and Haloarcula, haloarchaea species that are genetically similar have been found in hypersaline sites with global distribution [58]. Contemplating this biogeography of halophilic archaea, to explain spatial patterns of cultivatable microbial diversity, we considered GSL and its migrating avian population. We sought to test the hypothesis that birds could transport haloarchaea in salt crystals on their feathers from site to site reasoning that connecting patterns of migration [59] might explain how similar microorganisms appear over a long geographic distance. Migrating birds have been studied as potential (pathogenic) microbial vectors, which are usually a microorganism replicating within an avian host and being delivered to a new location via feces $[60,61]$. However, birds can also act as mechanical carriers, where the feathers of the animal serve to transport the microorganism $[60,62,63]$. Fungal spores, notorious for tolerating desiccation, were applied to feathers and found to survive for hours [63] or days [62], which are small time-frames compared to GSL microorganisms [28]. 


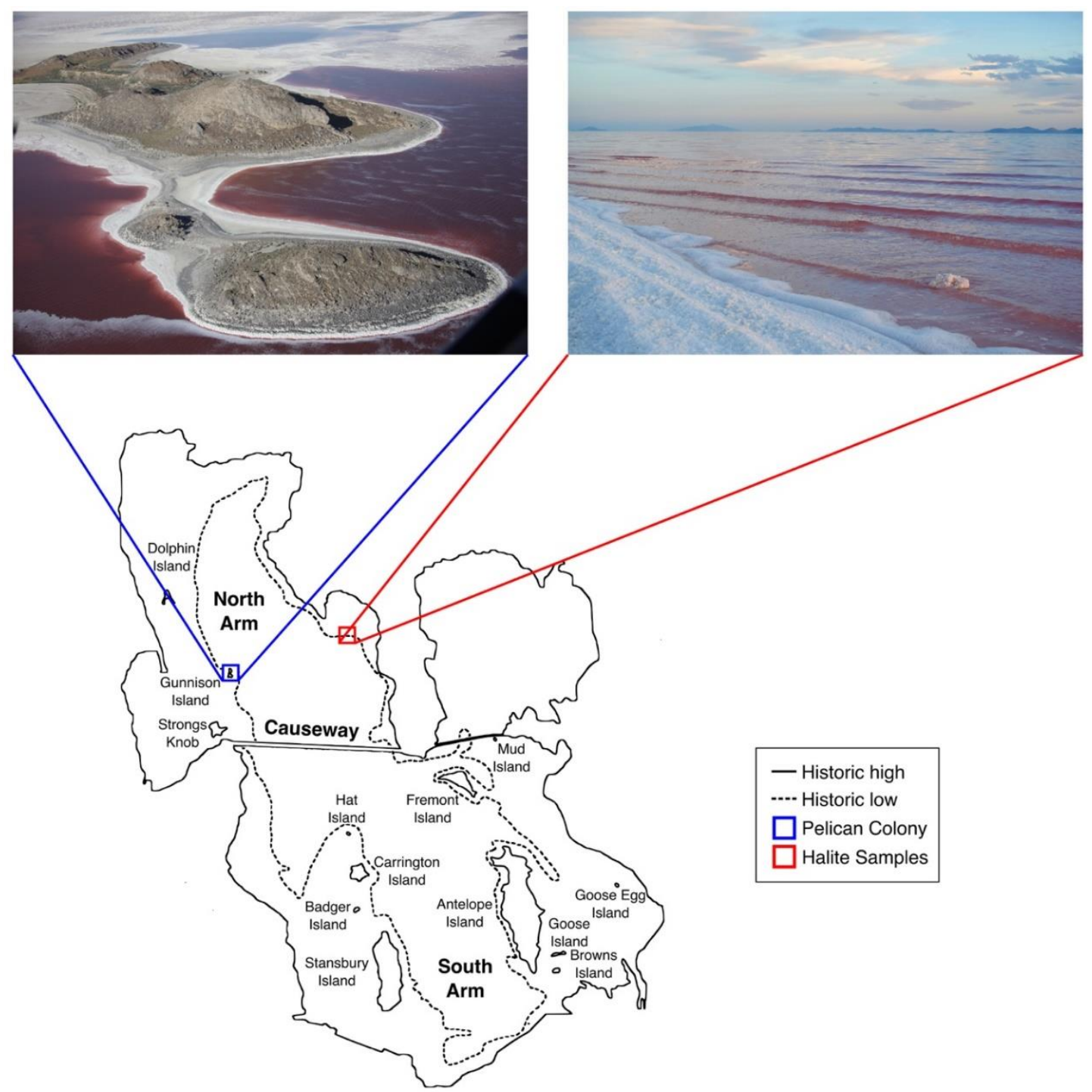

Figure 1. Map of Great Salt Lake depicting the location of the north arm sampling sites: the American White Pelican breeding colony on Gunnison Island (left, blue) and the location of Rozel Bay where halite was collected (right red). The island is a restricted access site as the breeding birds are protected by law. Since the elevation of Great Salt Lake fluctuates over time, we have indicated the high-water line and the historic low elevation. The railroad causeway that separates the hypersaline north arm from the south arm is shown, and the lake's islands are also indicated. The causeway length is $19 \mathrm{~km}$, which provides scale for this image. Image credit: Great Salt Lake Institute.

Since halophilic archaea can survive over geologic time in halite [2,7-21], and these crystals would likely form on feathers of birds feeding in GSL waters, we decided to investigate the ability of halophilic archaea in halite to be carried mechanically by migrating birds. Birds as vectors for haloarchaeal dispersal have been suggested by some studies on geographic distribution $[10,64,65]$ and shown by two: a Halococcus species was found in salt crystals collected from the nostril salt gland of a migratory bird [66] and a broad diversity of halophilic archaea were discovered on flamingo feathers [67]. In this report, we present evidence for the formation of halite crystals on feathers and their preservation of halophilic archaea. Specifically, we examined the haloarchaeal diversity of strains carried by AWPE, which live in the hypersaline north arm of GSL [50] and compared this to the microbial diversity of halite collected on a nearby shore of the lake. Examining the closest genetic relatives of the GSL strains, which were isolated around the globe, we present a distribution map and a model for avian dispersal and selection by hypersaline environments. 


\section{Materials and Methods}

\subsection{Collection, Cultures, and DNA Extraction}

Chest feathers were collected from AWPE from the Gunnison Island breeding colony under the migratory bird permit MB105510-0, which allowed for salvage and scientific collection of feathers from migratory birds at GSL. Feathers were photographed with a Dino-Lite digital microscope (AnMo Electronics Corporation, New Taipei City, Taiwan) at $100 \times$ magnification. Three feathers were individually placed in $8 \mathrm{~mL}$ of $23 \% \mathrm{NaCl}$ Modified Growth Media (MGM) [68], such that the feathers were submerged, for three weeks at $37^{\circ} \mathrm{C}$ with shaking until cultures were turbid. Salt crystals were collected from the shore at Rozel Bay in the north arm of GSL and dissolved and cultured with shaking in $5 \mathrm{~mL}$ of $23 \% \mathrm{MGM}$ for three weeks at $37^{\circ} \mathrm{C}$. Dilutions of each culture were spread on $23 \%$ MGM agar plates (three for each feather and salt crystal culture) and incubated at $37^{\circ} \mathrm{C}$ for three weeks. Ten colonies per plate were randomly selected and sub-cultured, into 23\% MGM liquid broth, from each plate. We extracted DNA from $1 \mathrm{~mL}$ of turbid culture with the FastDNA Spin Kit for Soil (MP Biomedicals, Santa Ana, CA, USA). The kit protocol was followed by an ethanol precipitation to further clean the DNA.

\subsection{PCR Amplification, DNA Sequencing and Genbank Comparisons}

To amplify a partial sequence of the archaeal 16SrRNA gene, we used the Taq PCR kit (New England Biolabs, Ipswich, Mass) and the halophilic archaeal primers: 1HK $\left(5^{\prime}\right.$ ATTCCGGTTGATCCTGCCGG 3') [69-72] and H589R (5' AGCTACGGACGCTTTAGGC 3') [45]. Initial denaturation was at $94{ }^{\circ} \mathrm{C}$ for 5 min followed by 45 cycles of denaturation $\left(94{ }^{\circ} \mathrm{C}\right.$ for $\left.30 \mathrm{~s}\right)$, annealing $\left(58^{\circ} \mathrm{C}\right.$ for $\left.60 \mathrm{~s}\right)$, and elongation $\left(72{ }^{\circ} \mathrm{C}\right.$ for $\left.60 \mathrm{~s}\right)$. The final elongation phase was $72{ }^{\circ} \mathrm{C}$ for $5 \mathrm{~min}[46,70]$. Amplification of this $~ 550$ bp product was observed by analysis on a $2 \%$ agarose gel, utilizing a tris acetate buffer. For successful amplifications, the PCR products were cleaned with a QIAquick PCR Purification Kit (Quiagen, Venlo, Netherlands) and then submitted to the Center for Integrated BioSystems at Utah State University for DNA sequencing, using the 1HK primer above for the sequencing reactions. Sequence data (deposited in GenBank, accession numbers MH746823-MH746869) were analyzed by the Basic Local Alignment Search Tool (BLAST) using the GenBank database [73]. Using these sequence data from the 16SrRNA gene segment, matched species were logged for each isolate.

\subsection{Geographic and Climate Data}

Closest-matched species were surveyed for sampling site locations, including longitude, latitude, and elevation. This information on previously deposited sequences was detailed in either Genbank, the supporting literature, and/or cell culture catalogs: the American Type Culture Collection (ATCC, Manassas, VA, USA); the Biological Resource Center (NBRC/JCM, Kyoto, Japan), the Leibniz Institute DSMZ (DSM, Braunschweig, Germany), and the All-Russian Collection of Microorganisms (VKM, Moscow, Russia). References for each strain match are included in Tables 1 and 2. For each site location, we collected data on the Köppen Climate Classification (KCC) categories [74], and other environmental parameters [75]. The KCC system identifies the main climate groups with the first letter: A (tropical), B (dry), C (temperate), and D (continental). The second letter represents seasonal precipitation subgroup: $\mathrm{m}$, monsoon; $\mathrm{W}$, wet savanna; $\mathrm{S}$, steppe; $\mathrm{W}$, desert; $\mathrm{f}$, rainforest; $\mathrm{s}$, dry savanna. The third letter represents a temperature pattern subgroup (for all groups other than those in the A group): $a$, hot summer; $b$, warm summer; $c$, cold summer; $d$, very cold winter; $h$, hot; $k$, cold. 


\subsection{Statistical Methods}

To address the question of parameters involved in selection of strains at each location, we analyzed environmental conditions of all sites. Statistical analyses were carried out using the $\mathrm{R}$ package stats version 3.5.0 (The R Foundation, Vienna, Austria). The average temperatures and annual precipitations among geographic sites of the closest-matched species (Table 1, Table 2, $n=50$ ) were combined and compared to those of GSL using one-sample t-tests, with each $\mu$ corresponding to the GSL value $\left(11.0{ }^{\circ} \mathrm{C}\right.$ and $393.2 \mathrm{~mm}$, respectively). These averages are reported in the text as $95 \%$ confidence intervals. It should also be noted that these sample data do not constitute a random sample.

\section{Results}

\subsection{Great Salt Lake American White Pelicans, Feathers, and Halite Crystals}

GSL boasts the second largest breeding colony of AWPE in the world [50,51] on Gunnison Island (Figure 1), which is protected as a refuge for the colony by the State of Utah [76]. These birds must travel to obtain fish since this food is not available in the lake waters surrounding their breeding grounds; therefore, it was generally assumed that they did not spend time in the salt-saturated water. Recently, however, this activity was caught by a motion-activated camera that we installed on Gunnison Island, in conjunction with Great Salt Lake Ecosystem Program (GSLEP) at the Utah Division of Wildlife Resources [77]. A number of our images indicate AWPE do indeed spend time in the brine e.g., (Figure 2a,b). Furthermore, we observed baby pelicans coated in salt crystals (Figure 2c) during the AWPE nestling banding effort [78]. These birds are present at GSL while breeding, March through September [79], then migrate south to Mexico, and some taking an inland path through the Southwestern U.S. [80]. They also move back and forth to freshwater lakes in the Western U.S., and GSL is a "clear central hub of the western population" (R. Norvell, personal communication, citing unpublished data from the State of Utah).
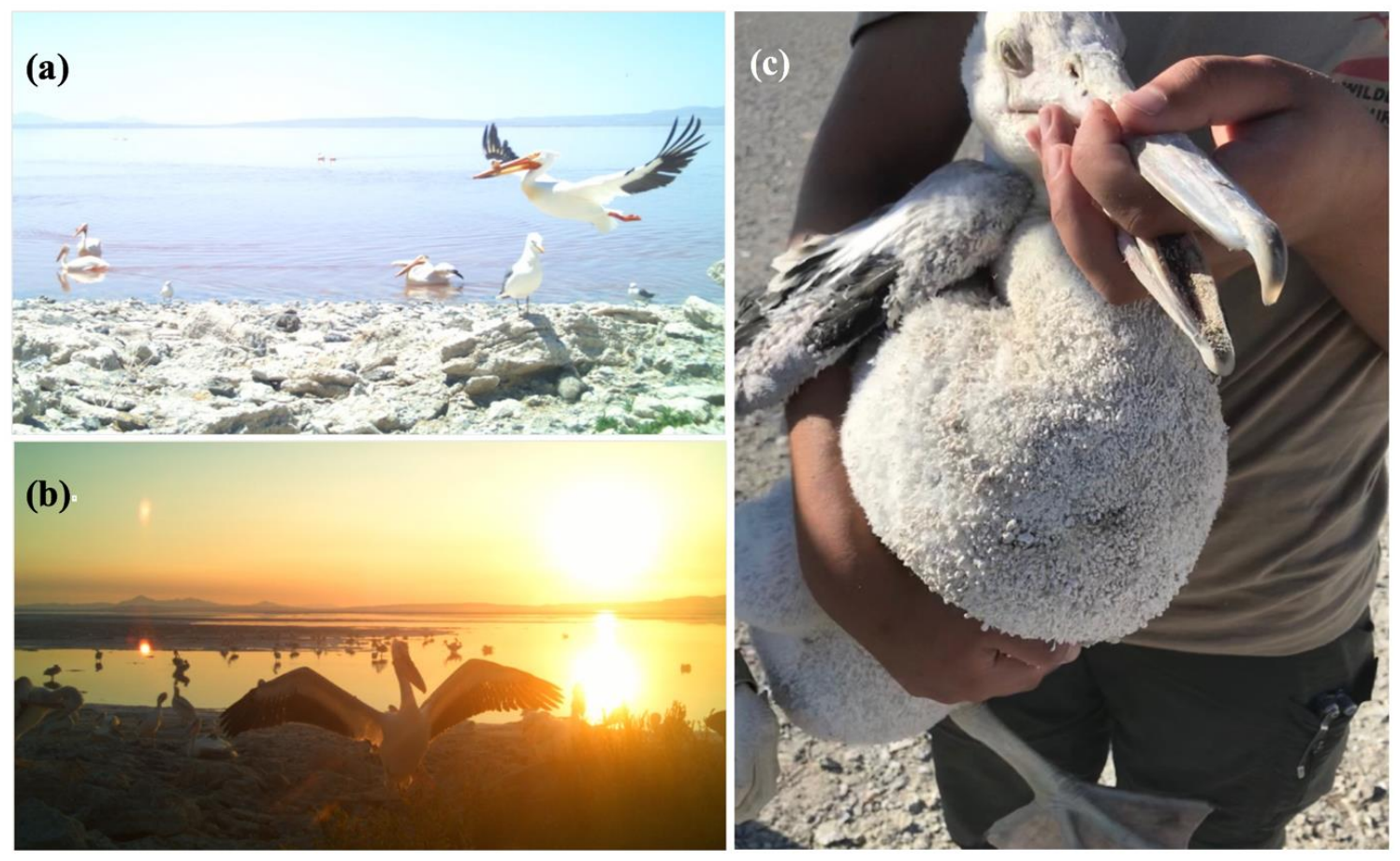

Figure 2. Gunnison Island American White Pelicans (AWPE). (a) and (b) Images from a motion-activated trail camera showing AWPE in contact with Great Salt Lake north arm hypersaline water, image credit: PELIcam sponsored by Great Salt Lake Institute at Westminster College and the Utah Division of Wildife, Great Salt Lake Ecosystem Program. (c) A baby AWPE on Gunnison Island, coated in salt crystals, image credit: Great Salt Lake Institute at Westminster College. 
Since migrating AWPE do spend time in water teeming with halophilic archaea [5], we wondered if the feathers from adults contained halite crystals that might preserve, and potentially disperse, the microorganisms. We collected then photographed AWPE chest feathers and found small halite crystals (1-2 mm width) associated with each feather tested (Figure 3a). We harvested larger halite crystals $(1-3 \mathrm{~cm})$ (Figure $3 \mathrm{~b}$ ), from the north arm shore (Figure 1) typical of hopper salt crystals that are prevalent in the fall, when the water temperature decreases and salt precipitates. This halite would serve as a control to assess preserved microbial diversity in GSL crystals not associated with feathers, allowing us to look at the commonality of microbial communities of lake halite versus that which may be carried on the pelicans.
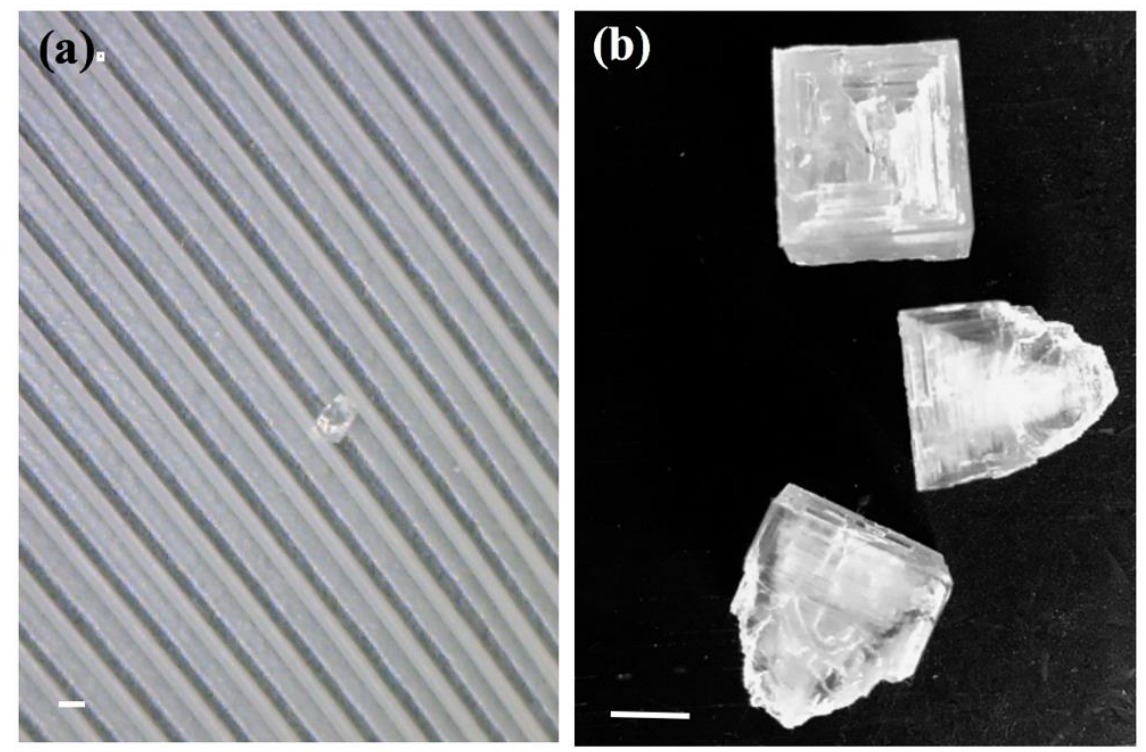

Figure 3. Halite crystals from Great Salt Lake. (a) A tiny halite crystal on a feather from an American White Pelican from the breeding colony on Gunnison Island, scale bar is $1 \mathrm{~mm}$. (b) Hopper halite crystals collected from Rozel Bay, scale bar is $1 \mathrm{~cm}$.

\subsection{Halophilic Archaea Diversity of American White Pelican Feathers and Halite Crystal Cultivars}

To investigate the possibility of microorganisms living on the feathers or in the halite on the feathers, we incubated AWPE feathers in salt broth media and then plated cultures on solid media (Figure 4a). Colonies from these plates were sub-cultured and DNA was extracted from isolated strains. We amplified a partial 16S rRNA gene sequence for each isolate, which resulted in PCR products the expected size as predicted by primer location (Figure 4b). DNA sequencing of the amplification products confirmed the microorganisms were halophilic archaea (Table 1).

Table 1. Halophilic archaea isolates cultured from Great Salt Lake American White Pelican feathers. For each isolated cultivar, we have listed the closest-matched species/strain and percent similarity (\% Sim) in the partial 16S rRNA gene sequence. For the sampling sites of matched strains, we have indicated the geographic location and reference for the study, Köppen Climate Classfication (KCC) [74], EL, Elevation Level (EL) in meters above sea level; Average Rainfall (AR), and Average Temperature (AT). DNA sequence information is available in the GenBank database, under accession numbers MH746823-MH746869.

\begin{tabular}{ccccccc}
\hline Matched Strain & \% Sim & Location [Reference] & KCC & $\begin{array}{c}\text { EL } \\
(\mathbf{m})\end{array}$ & $\begin{array}{c}\text { AR } \\
(\mathbf{m m})\end{array}$ & $\begin{array}{c}\text { AT } \\
\left({ }^{\circ} \mathbf{C}\right)\end{array}$ \\
\hline Haloarcula amylolytica & 99 & Kachchh Salt Pans, Gujarat, India [81] & BSh & 5 & 753 & 27.3 \\
Haloarcula amylolytica & 99 & Xinjiang, China [82] & BSk & 408 & 514 & 13.2 \\
\hline
\end{tabular}


Table 1. Cont.

\begin{tabular}{ccccccc}
\hline Matched Strain & \% Sim & Location [Reference] & KCC & $\begin{array}{c}\text { EL } \\
(\mathbf{m})\end{array}$ & $\begin{array}{c}\text { AR } \\
(\mathbf{m m})\end{array}$ & $\begin{array}{c}\text { AT } \\
\left({ }^{\circ} \mathbf{C}\right)\end{array}$ \\
\hline Haloarcula argentinensis & 99 & Leh-Ladkh, Rohtang Pass, India [83] & Dwd & 3978 & 27 & 3.75 \\
Haloarcula argentinensis & 99 & Salinas Chica, Chubut, Argentina [84] & BSk & -20 & 206 & 13.5 \\
Haloarcula hispanica & 99 & Santa Pola, Alicante, Spain [44] & Csa & 10 & 66 & 26 \\
Haloarcula japonica & 99 & Noto Peninsula, Japan [85] & Cfb & 438 & 180.016 & 13.75 \\
Haloarcula marismortui & 99 & Mumbai salterns, India [86] & Am & 14 & 242.2 & 27.2 \\
Haloarcula marismortui & 98 & Dead Sea, Israel [87] & Csa & -430.5 & 50 & 25.5 \\
Haloarcula quadrata & 99 & Kachchh Salt Pans, Gujarat, India [81] & BSh & 5 & 753 & 27.3 \\
Haloarcula quadrata & 99 & Salada, Murcia, Spain [88] & BSk & 4 & 297 & 18.6 \\
Haloarcula quadrata & 99 & Sebkha Gavish, Southern Sinai, Egypt [89] & BWh & 13 & 40 & 24.4 \\
Haloarcula salaria & 99 & Kachchh Salt Pans, Gujarat, India [81] & BSh & 5 & 753 & 27.3 \\
Haloarcula salaria & 99 & Thailand (Thai fish sauce) [90] & Aw & 0 & 1184 & 25.6 \\
Haloarcula tradensis & 99 & Thailand (Thai fish sauce) [90] & Aw & 0 & 1184 & 27.3 \\
Haloarcula sp. strain SP2(1) & 100 & Kachchh Salt Pans, Gujarat, India [91] & Am & 14 & 242.2 & 27.2 \\
Haloarcula sp. strain I.C6 & 100 & Isla Cristina, Southern Spain [92] & Csa & 11 & 612 & 17.8 \\
Haloarcula sp. strain D21 & 100 & Chott Melrhir, Algeria [93] & BWh & -40 & 160 & 22.8 \\
\hline
\end{tabular}

Table 2. Halophilic archaea isolates cultured from Great Salt Lake shore halite crystals. For each isolated cultivar, we have listed the closest-matched species/strain and percent similarity (\% Sim) in the partial $16 \mathrm{~S}$ rRNA gene sequence. For the sampling sites of matched strains, we have indicated the geographic location and reference for the study, Köppen Climate Classfication (KCC) [74], EL, Elevation Level (EL) in meters above sea level; Average Rainfall (AR), and Average Temperature (AT). DNA sequence information is available in the GenBank database, under accession numbers MH746823-MH746869.

\begin{tabular}{|c|c|c|c|c|c|c|}
\hline Matched Strain & $\%$ Sim & Location [Reference] & KCC & $\begin{array}{c}\text { EL } \\
(\mathrm{m})\end{array}$ & $\begin{array}{c}\text { AR } \\
(\mathrm{mm})\end{array}$ & $\begin{array}{c}\text { AT } \\
\left({ }^{\circ} \mathrm{C}\right)\end{array}$ \\
\hline${ }^{*}$ Haloarcula argentinensis & 100 & Salinas Chica, Chubut, Argentina $[84,94]$ & BSk & -20 & 206 & 13.5 \\
\hline${ }^{*}$ Haloarcula hispanica & 99 & Santa Pola, Alicante, Spain [44] & Csa & 10 & 66 & 26 \\
\hline Haloarcula hispanica & 100 & Santa Pola, Alicante, Spain [95] & Csa & 10 & 66 & 26 \\
\hline${ }^{*}$ Haloarcula japonica & 100 & Noto Peninsula, Japan [85] & Cfa & 438 & 180.016 & 13.75 \\
\hline${ }^{*}$ Haloarcula marismortui & 100 & Dead Sea, Israel [87] & Csa & -430.5 & 50 & 25.5 \\
\hline${ }^{*}$ Haloarcula quadrata & 100 & Sebkha Gavish, Southern Sinai, Egypt [89] & BWh & 13 & 40 & 24.4 \\
\hline${ }^{*}$ Haloarcula salaria & 99 & Thailand (Thai fish sauce) [90] & Aw & 0 & 1184 & 27.3 \\
\hline Haloarcula sinaiiensis & 100 & Sebkha Gavish, Southern Sinai, Egypt [96] & BWh & -999 & 60 & 26.5 \\
\hline${ }^{*}$ Haloarcula tradensis & 100 & Thailand (Thai fish sauce) [90] & Aw & 0 & 1184 & 27.3 \\
\hline Haloarcula vallismortis & 100 & Death Valley, CA, USA [97] & BSk & -86 & 60 & 27.2 \\
\hline Halorubrum arcis & 100 & Tibetan Plateau, China [98] & BWk & 4500 & 43 & 4.8 \\
\hline Halorubrum californiense & 100 & Balearic Islands, Spain [99] & BSk & 13 & 449 & 18.2 \\
\hline Halorubrum californiense & 100 & Newark, California, USA [100] & Csc & 6 & 368 & 15 \\
\hline Halorubrum chaoviator & 100 & Santa Pola, Alicante, Spain [33] & BSh & 6 & 317 & 18.2 \\
\hline Halorubrum chaoviator & 100 & Saharan Saline Syst., Southern Tunisia $[101,102]$ & Csa & -22.5 & 100 & 20 \\
\hline Halorubrum chaoviator & 99 & Yuli, Bayingol, Xinjiang, China [103] & BWk & 900 & 30 & 11 \\
\hline Halorubrum chaoviator & 100 & Baja California, Mexico [36] & $\mathrm{Csb}$ & 660 & 116.8 & 18.2 \\
\hline Halorubrum ejinorense & 100 & Lake Ejinor, Inner Mongolia, China $[37,104]$ & BSk & 1065 & 391 & 6.4 \\
\hline Halorubrum ezzemoulense & 100 & Sebkhet ez Zemoul, Oum el Bouaghi, Algeria [105] & BSk & 850 & 382 & 14.5 \\
\hline Halorubrum ezzemoulense & 100 & Sfax solar saltern, Tunisia [106] & BWh & 0 & 212 & 19 \\
\hline Halorubrum litoreum & 99 & Xiuyu, Fujian, China [107] & Cfa & 21 & 1178 & 20.9 \\
\hline Halorubrum tebenquichense & 100 & Patagonian salt flat, Argentina [108] & BSk & 175 & 685.8 & 19.5 \\
\hline Halorubrum tebenquichense & 100 & Atacama saltern, Chile [109] & BWk & 2339 & 7 & 17 \\
\hline Halorubrum terrestre & 100 & Ashgabat, Turkmenistan [110] & BSk & 219 & 228 & 15.4 \\
\hline Halorubrum terrestre & 100 & Gyaur-Kala, Turkmenistan $[110,111]$ & BWk & 252 & 124 & 14.8 \\
\hline Halorubrum trapanicum & 99 & Turkmenistan [110] & BWk & 281 & 124 & 14.8 \\
\hline Halorubrum xinjiangense & 99 & Xiao-Er-Kule Lake, Xinjiang, China [112] & BWk & 4475 & 105 & 11.5 \\
\hline Halorubrum sp. strain SP9-2 & 98 & Red Sea [113] & Csa & -400 & 41.9 & 26.1 \\
\hline Halorubrum sp. strain spIB11 & 98 & Isla Bacuta and Isla Cristina, Huelva, Spain [92] & Csa & 8 & 467 & 17.8 \\
\hline Halorubrum sp. strain SS13-13 & 98 & Samut Sakhon, Thailand [114] & Aw & 7 & 1330 & 27.8 \\
\hline Halorubrum sp. strain Y122 & 99 & Yunnan Salt Mine, China [115] & Cwb & 1892 & 570.7 & 15.2 \\
\hline Halorubrum sp. strain Y62 & 99 & Yunnan Salt Mine, China [37] & Cwb & 1892 & 570.7 & 15.2 \\
\hline Halorubrum sp. strain YC-11 & 98 & Yuncheng Salt Lake, Shanxi, China [37] & BSk & 353 & 74.7 & 14.05 \\
\hline
\end{tabular}

* These strains are similar or identical to the ones isolated from feathers shown in Table 1. 

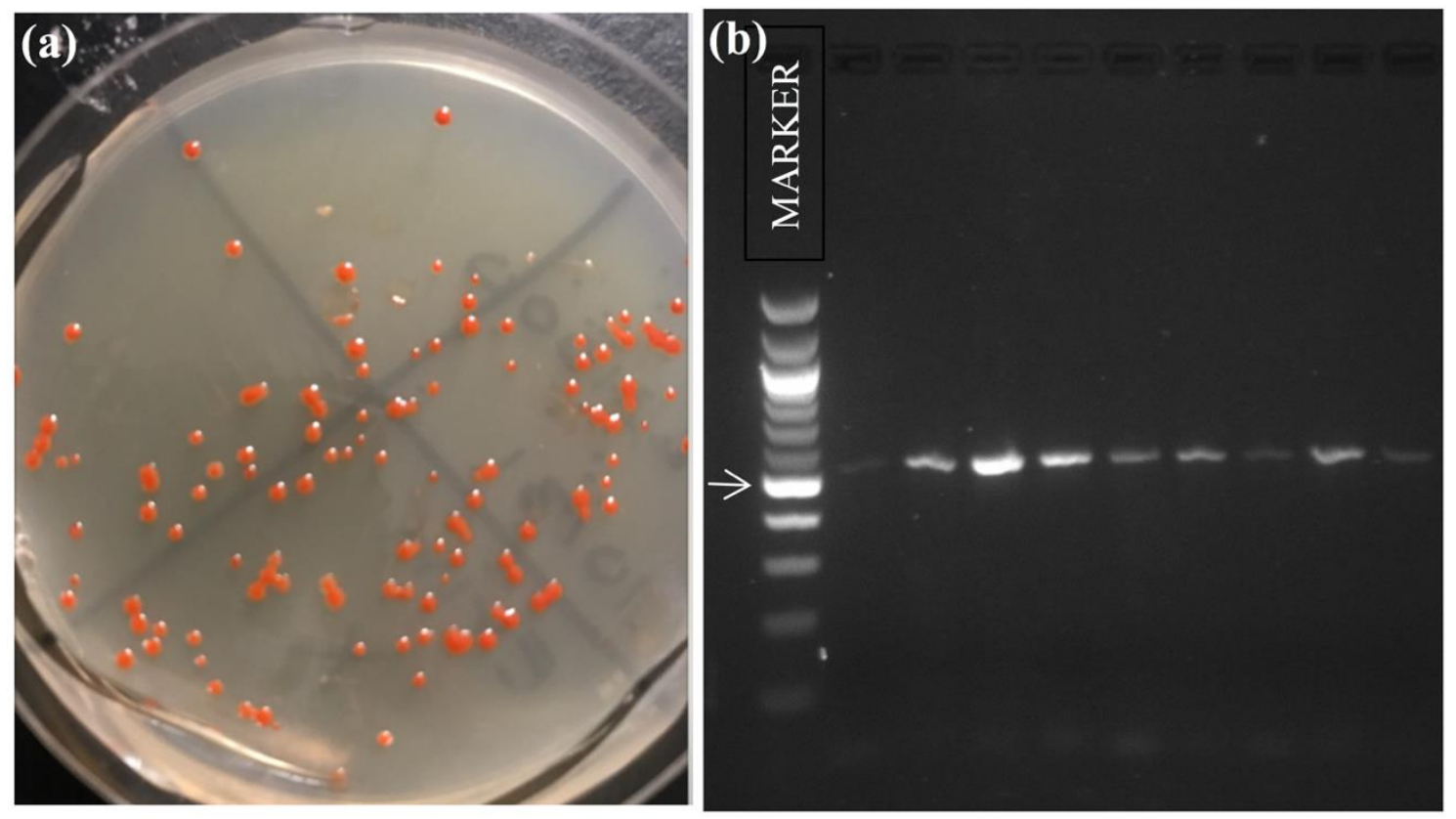

Figure 4. Evidence for microorganisms associated with the feathers of American White Pelicans. (a) Cultures generated by incubating feathers in salt media broth were plated on the same media in solid form; one such plate is shown. These colonies represented mixed species of halophilic archaea, and we selected ten randomly from each plate by quadrants for analysis. (b) Representative PCR amplification of the 16SrRNA gene from isolated species of halophilic archaea from feather cultures. The marker (100 bp DNA ladder, New England Biolabs) is in lane one, and the arrow indicates the migration of two lengths of DNA combined: $500 \mathrm{bp}$ and $517 \mathrm{bp}$. Amplification with haloarchaeal primers resulted in the estimated range of $550-560 \mathrm{bp}$ bands. expected for this segment of the $16 \mathrm{~S}$ rRNA gene in halophilic archaea. Negative controls, PCR reactions with no template DNA, showed no amplification product.

Each $16 \mathrm{~S}$ rRNA gene partial DNA sequence was compared in BLAST searches, and the closest-matched species were recorded. All isolates aligned with the Haloarcula genus according to homology in this segment of the gene. Table 1 lists the most similar GenBank BLAST hits for these related species of each cultivar. We also recorded the sampling location of each matched strain in the database to gather data on geographic distribution of strains similar to our GSL strains isolated from the AWPE feathers (Table 1).

We repeated this procedure for the shore-collected halite crystals (Figure 3b), from which we cultivated dozens of halophilic archaea. The closest matched species for each GSL halite isolate were logged (Table 2). The halite-derived strains were classified as either in the Haloarcula genus, as with the feather-derived strains, or in the Halorubrum genus. We investigated the sampling locations of these related species as well, and these sites are presented in Table 2. Clearly, both genera are capable of surviving in halite crystals and can be cultured from them, in contrast to the cultivation experiments with AWPE feathers where only Haloarcula cultivars were obtained (Table 1).

\subsection{Geographic Distribution Patterns of Closest-Matched Strains}

How do related Halorubrum and Haloarcula strains exist in environments separated by large distances around the planet? To create a model, we first plotted the geographic distribution of the strains matching our GSL feather and halite isolates. Figure 5 shows the sampling site location of these closest-matched strains as indicated by the referenced studies (Tables 1 and 2). The distribution of these similar halophilic archaea strains indicated a pattern of two belts around the Earth, aligned with the (north and south) sub-tropical jet stream, demarked with bold latitude lines on the map projection 
(Figure 5). Moreover, the strains matched to the GSL feather isolates showed a similar distribution to the those of the GSL halite isolates.

A microorganism's molecular signature evolves over time due to selection by various environmental adaptations along with genomic diversity. Environmental factors such as temperature, $\mathrm{pH}$, and concentrations of individual ions were shown to give rise to adaptations in halophilic archaea [116]. Potential environmental parameters that could enable the selection of microorganisms may relate to climate. To examine commonalities in climate among the geographic sites corresponding to each closest-matched species (Tables 1 and 2), we classified each site by its Köppen climate category (Figure 6). The Haloarcula and Halorubrum species favored dry (52\%) and temperate (32\%) climates, with the most frequent classification being cold semi-arid (BSk; 22\%), which is the same category as GSL.

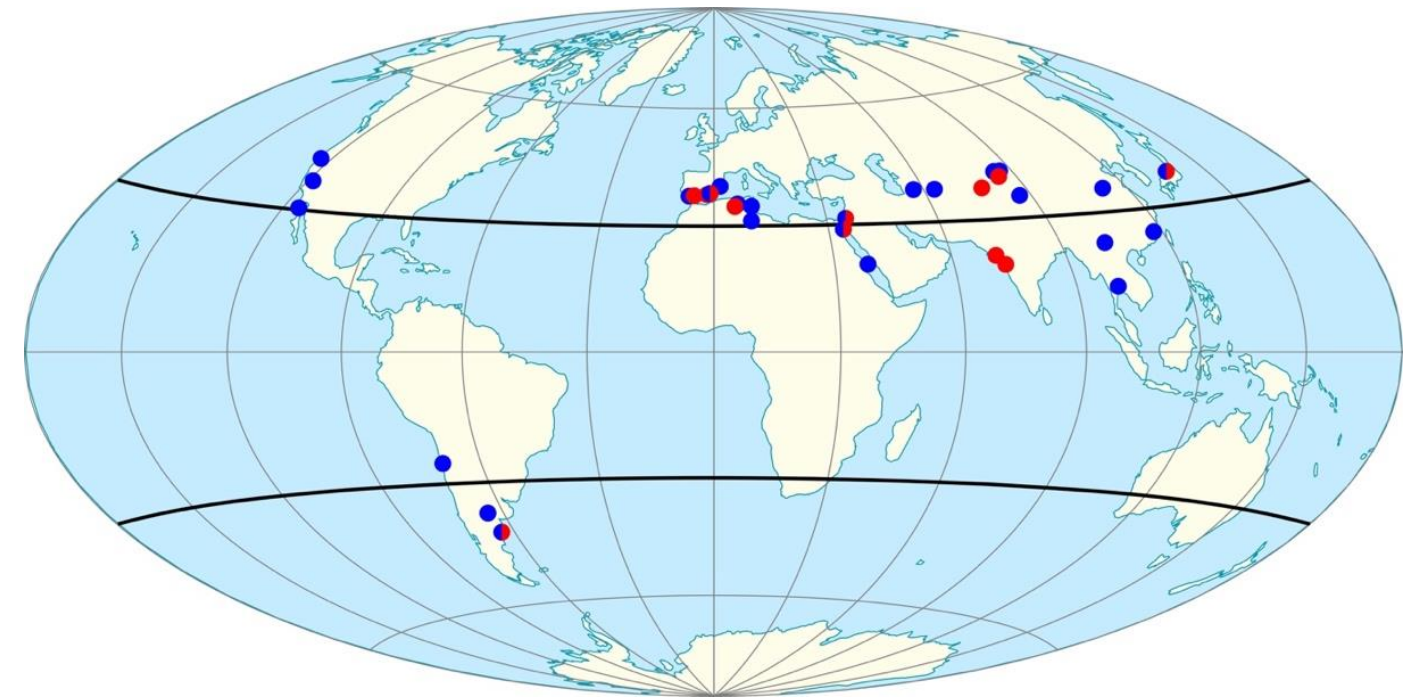

Figure 5. Geographic distribution of halophilic archaea species/strains matched by16S rRNA homology to Great Salt Lake isolates. Red circles indicate matches from cultivars isolated from feathers (Table 1) and blue circles indicate those from shore halite (Table 2). The darkened lines indicate the boundaries of the Subtropical jet streams (North and South). Image credit: Great Salt Lake Institute at Westminster College using map projection available from Creative Commons.

\subsection{Environmental Factors as Variables in Distribution and Selection}

Additionally, we collected data for the average annual precipitation, and average temperature, and elevation at the geographic sites corresponding to each closest-matched species (Tables 1 and 2) in order to evaluate climate parameters more specifically and compare them to GSL. The average annual precipitation among the sample sites $(365.5 \pm 108 \mathrm{~mm})$ was not significantly different from GSL (393.2 $\mathrm{mm} ; p=0.6)$. In contrast, the average temperature $\left(19.6 \pm 1.9^{\circ} \mathrm{C}\right)$ was significantly different from GSL $\left(11.0^{\circ} \mathrm{C} ; p=9 \times 10^{-12}\right)$. Elevation among the sample sites showed a high degree of variability $(\mathrm{min}=-999 \mathrm{~m} ; \max =4500 \mathrm{~m} ;$ median $=10.5 \mathrm{~m})$ and was not statistically compared to GSL $(1280 \mathrm{~m})$. We should note that GSL experiences significant seasonal temperature variation, from $0.5^{\circ} \mathrm{C}$ in January to $26.7^{\circ} \mathrm{C}$ in July [117] and up to $45^{\circ} \mathrm{C}$ in the shallow margins [118] due to its elevation and arid setting.

Beyond climate, a key environmental variable common to all sampling sites was salinity: all sites contained either brine at salt-saturation, crystalline halite, or saline soils. Therefore, this suggests that salinity is a significant driver for selection of Halorubrum and Haloarcula strains, not unexpected since these species are defined by their salt requirement. 


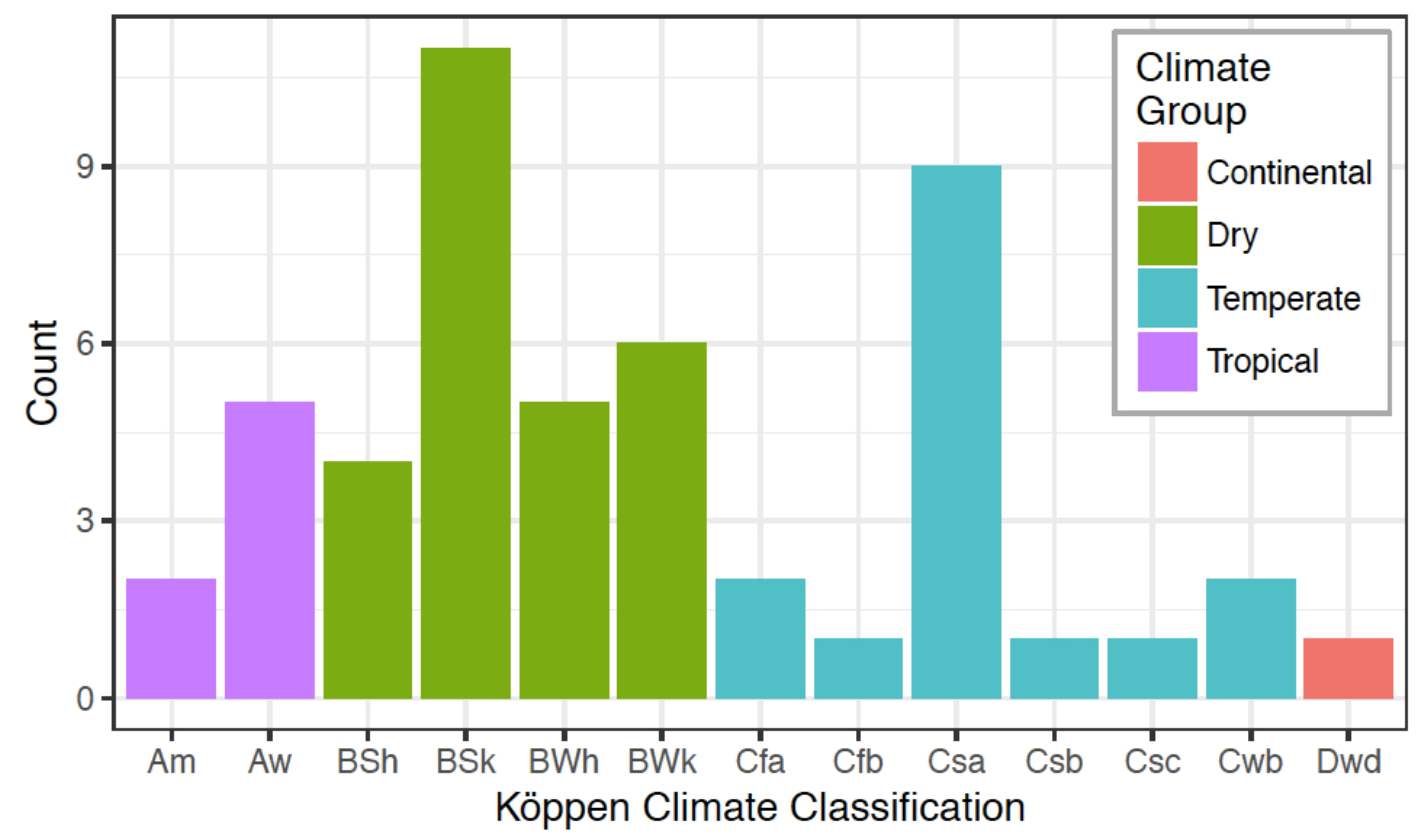

Figure 6. Köppen climate classification (KCC) categories [74], see methods, for geographic sites from where each Halorubrum and Haloarcula closest matched species (Tables 1 and 2) was sampled.

\section{Discussion}

To explain the vast diversity of microorganisms and their overlapping geographic distributions, Baas-Becking famously postulated that "everything is everywhere, but the environment selects" [119]. Others, such as Finlay, supported this model, suggesting that, due to microorganisms' small size, abundance, and metabolic plasticity, they could truly exist in many environments, dormant and in small numbers, making them difficult to detect until conditions selected for their growth e.g., [120]. More recent studies, using molecular techniques, have disputed this idea of cosmopolitanism and suggested mechanisms of distribution, such as active propulsion, atmospheric deposition, or traveling by mechanical carriers, to explain the biogeography e.g., [121-124]. In either case, microbial diversity studies reveal that environmental parameters influence biogeographical patterns $[125,126]$.

How does this relate to the Halorubrum and Haloarcula genera with globally-distributed species which are genetically related? Which environmental parameters are important in selection? Halophilic archaea are metabolically flexible with respect to temperature, $\mathrm{pH}$ and desiccating conditions. A survey of all studied halophilic archaea suggests that these cells have broad $\mathrm{pH}$ and temperature ranges [127]. Siroosi and coworkers noted that Halorubrum sp. strain Ha25 grew and produced protein over a range of temperature $\left(30-55^{\circ} \mathrm{C}\right)$ and over a $\mathrm{pH}$ range (6.0-8.0) [128]. A Haloarcula strain from Great Salt Lake, which was studied under temperature and salinity stress outside of optimal ranges, adjusted to changing environmental changes by gene regulation, which may provide some insight into the mechanisms of its flexibility with environmental conditions [45]. Under space exposure conditions, in which the temperature ranged from -24.6 to $+49.5{ }^{\circ} \mathrm{C}$, Halorubrum chaoviator survived and grew vegetatively when it was returned to the laboratory on Earth [23]. Thus, it may not be surprising to observe a Halorubrum species surviving the cold temperatures of a Tibetan Plateau and another of the same genus in the warmth of Baja, California (Table 2).

In continuing to think about selection, we applied statistical analyses to compare the climate and environmental parameters of each site location of our closely matched strains (Tables 1 and 2). Here, we were not asking a question about dispersal mechanisms, but instead looking for commonalities among isolation sites for these halophilic archaea. As shown in Figure 6, dry and temperate conditions were favored, but the broad distribution of climate classifications points again to the flexibility of these species. As expected, given the climate classification results, a statistical analysis 
of elevation, rainfall and temperature data showed a large range across all of the sites. When we compare this environmental factor analysis of sites to our primary site of GSL, we see that GSL matches the most frequent (cold semi-arid) Köppen Climate Classification of BSk, and the rainfall at GSL is not significantly different from the average of the other global sites. However, the average temperature at the GSL site is distinct from that averaged from all of the other sites. Our data, and numerous other studies [e.g summarized in 127], indicate that high salinity is necessary for these archaea to thrive and is most certainly the most important environmental parameter for selection.

Were dormant cells already in existence before a salt lake, halite evaporite, or solar saltern was formed? Or is it more likely that these cells could hitchhike by wind, water, or animal and thrive in high salt areas in which they were deposited? We certainly would expect more divergent and distinct populations than we observe if these sites were physically isolated from one another [129], which suggests there is a vector, or dispersal mechanism, between the sites. A study comparing Haloquadratum walsbyi strains, using 16S rRNA gene clone libraries, showed that despite the large geographical distance separating the salterns in which they each dwell, there are only minor sequence differences [64]. However, we may not see true phenotypic diversity among the same species when analyzing only this partial 16S rRNA gene. Studies on the halophilic bacteria, Salinibacter ruber, demonstrated three separate geographic populations based on a study of metabolites in addition to gene sequences [130]. In addition, $16 \mathrm{~S}$ rRNA gene analyses are limited in biogeography studies since the slow rate of evolution that makes this gene a powerful tool across genera [131] can be problematic at the subgenus-level where few changes are detectable [132]. There is a special caveat for some Halobacteriaceae, for example Haloarcula, that have multiple divergent copies of the $16 \mathrm{~S}$ rRNA genes, which have DNA sequence differences that approach that expected from distinct genera [133-137].

The study presented here demonstrates that feathers of AWPE can harbor small halite crystals and also halophilic archaea, in particular Haloarcula species. The control shore-collected halite demonstrated the presence of both Halorubrum and Haloarcula, which are both overrepresented in culturing experiments [32,33]. Also, both of these genera persist in salt over geologic time [17]. Since our work relied on cultivation in both cases, we certainly suspect there are many more genera present than we cultured, as past studies have indicated [138]. We are curious about why only Haloarcula were cultured from feathers. Is this simply artifactual, based on the small number of feathers tested? Or is this because the associated halite crystals are relatively small in size, with tiny fluid inclusions, limiting preserved cells by size or shape? Haloarcula are flagellated triangular-shaped cells with in the size range of $2-5 \mu \mathrm{m} \times 0.3-0.5 \mu \mathrm{m}[139,140]$. We have observed their unique swirling swimming motion in dark field microscopy of our feather isolates (data unpublished). Although this genus was once considered nonmotile, the movement of these cells is now characterized [139,141]. Halorubrum are typically similar in size, but not in shape; they are usually pleomorphic rods, and their locomotion is very different [104]. Smaller halite crystals may have tiny fluid inclusions or channels and may select for specific cells based on locomotion and/or morphology.

The global biogeography of similar halophilic archaea e.g., (Figure 5) begs the question of dispersal mechanisms. Microorganisms could certainly travel by water as ocean water currents could move them around the planet and into more hypersaline areas (e.g., salterns or lagoons). Some researchers have explored the idea of seawater as a means of dispersal of halophilic archaea since some genera were detected in lower salinity environments such as marshes and marine sites despite their high salt requirement $[2,142,143]$. In such a model, microorganisms could travel via water but not thrive until they reached conditions with higher salinity, perhaps existing in some sort of metabolic dormancy [142]. Over geologic time, this could explain their prevalence in sites that were ancient seas, such as salt deposits, or inland lakes that formed originally from a seawater source e.g., [17]. And perhaps prehistoric halophilic archaea, trapped in ancient halite fluid inclusions, can even be released into the modern environment as deposits weather or come in contact with surface water.

Another potential dispersal mechanism involves the encysted embryos of the Artemia, which are collected by brine shrimp harvesters in the autumn months at GSL $[56,144]$. These cysts, which are 
only $0.2 \mathrm{~mm}$ in diameter, are buoyant and sticky, and they contain halophilic bacteria and archaea [46]. While GSL birds are feeding on shrimp in the brine, cysts may get lodged in feathers (although we did not observe them in our feather microscopy). In addition, cysts are picked up and deposited by wind as evidenced by their appearance on the upper shores of GSL. So Artemia cysts can travel by birds, water, and wind, but we should note they also travel by airplanes. The Artemia industry delivers GSL cysts around the world as a product used by aquaculture industries, and these cysts hatch in marine systems such as prawn farms in southeast Asia [144]. Thus, GSL microorganisms are delivered by cysts, via human transport, to various marine environments.

Aerial transport and dispersal are also possible for halophilic archaea as the desert ecosystems surrounding salt lakes and playa are prone to dust events [145]. Dust particles can create an "atmospheric bridge" between systems, assisting the deposition of microbiota downwind. Long-distance transport of microorganisms (spores) was demonstrated more than 60 years ago [146]. Perhaps more relevant here, halophilic bacteria were found in non-saline environments in Tokyo, Japan, suggesting they were transported from high saline environments elsewhere, based on air currents, likely from Inner Mongolia or salterns at the Yellow Sea or Japan Sea in Korea [147]. This study examined the directionality of storm patterns, which is suspected of delivering dust over $6000 \mathrm{~km}$ away [148]. Other studies have focused on the aerobiology of human pathogens reviewed in [149]. Even without birds, it is clear that microorganisms may travel on dust in the jet stream, but this does not negate avian carriers as an additional dispersal mechanism, especially for halophilic archaea since birds may travel directly from salty place, to salty place. This is the hypothesis we intended to shed light on with our work presented here.

Two observations led us to suspect birds as mechanical carriers for halophilic archaea: (1) ten million migrating birds visit GSL per year [48-52], and (2) halophilic archaea are resistant to desiccation $[150,151]$. In addition, birds as vectors for dispersal of halophilic microorganisms in halite crystals was demonstrated previously by the discovery of a Halococcus species in salt crystals associated with a migratory bird [66]. The biogeography of related Halorubrum and Haloarcula species (Figure 5) can be backed up by connecting migration routes of birds. For example, a GSL bird may travel the Pacific flyway to Mexico, and birds in Mexico may travel to South America, and birds in South America may fly across the Atlantic, leading to the other continents [152]. Our study highlighted the AWPE, a short-distance migrator, whose path follows GSL to coastal California, or inland down to Mexico [80]. However, a pattern of connecting overlapping migration routes for distribution, with the premise that halophilic archaea can hitchhike on one bird and be picked up at the next location by another, is plausible. The recent study on halophilic archaea transport by flamingoes underscores this principle [67]. Avian migration routes are typically within the flowing airspace of the troposphere where they travel $10-15 \mathrm{~m} / \mathrm{s}$, and the moving winds may even surpass this speed, impacting flightpaths $[153,154]$. The biogeography of genetically similar haloarchaea strains (Figure 5), shows a pattern, a double belt around the planet (between latitudes $45^{\circ} \mathrm{N}$ and $45^{\circ} \mathrm{S}$ ). This correlates with the north and south (sub-tropical) jet streams, which represents strong eastern winds $(25-70 \mathrm{~m} / \mathrm{s})$ in the upper portion of the troposphere. Migrating birds typically fly approximately $1000 \mathrm{~m}$ above the Earth below in this band of strong winds e.g., [152].

\section{Conclusions}

The AWPE, an avian visitor to GSL spends time in the salt-saturated north arm of GSL (Figure 2), and their feathers may harbor halite crystals (Figure 3a) and halophilic archaea (Figure 4). A number of strains from two genera, Halorubrum and Haloarcula, were found in GSL halite and on feathers, and these strains have genetic relatives around the world (Figure 5; Tables 1 and 2). An examination of climate conditions for these sites (Figure 6) pointed primarily to salinity as the defining selection parameter. Plotting the location of related strains revealed a correlation with the jet stream in the troposphere, a zone of bird migration patterns (Figure 5). Although there are a number of models for 
the dispersal of such microorganisms, and all may be at play, this study supports the model of avian mechanical carriers in the global distribution of halophilic archaea.

Author Contributions: Conceptualization, B.L.K., E.M.T., A.J.W. and B.K.B.; Data curation, B.K.B.; Formal analysis, B.L.K., E.M.T., A.J.W., D.L.J., J.K.B. and B.K.B.; Funding acquisition, J.K.B. and B.K.B.; Investigation, B.L.K., E.M.T., A.J.W., D.L.J., J.K.B. and B.K.B.; Methodology, B.K.B.; Project administration, J.K.B. and B.K.B.; Resources, B.K.B.; Software, D.L.J.; Supervision, B.K.B.; Validation, D.L.J.; Visualization, B.K.B., E.M.T., A.J.W., D.L.J., J.K.B. and B.K.B.; Writing-original draft, B.L.K., E.M.T., A.J.W., D.L.J., J.K.B. and B.K.B.; Writing-review \& editing, B.K.B.

Funding: This research was funded by the NASA SPACE GRANT PRIME AWARD (NNX15A124H, Sub-Award 10037896WEST), the W.M. KECK FOUNDATION, and the LAWRENCE T. AND JANET T. DEE FOUNDATION.

Acknowledgments: The authors thank John Neill and the Great Salt Lake Ecosystem Program (State of Utah, Division of Wildlife Resources) for their amazing role as collaborators in studying the AWPE of Gunnison Island. Their assistance with boats and access, providing monitoring data, additional field trips, and general knowledge of the birds is critical to the work of many researchers. Also, we express gratitude to Stephanie Graham, a wildlife biologist with the US Fish and Wildlife Service who collected feathers under their permit. Westminster students Brett Denny and Josh Webb were responsible for collecting and initially culturing from the GSL halite, and the Westminster College Principles of Genetics course students (Fall 2016) assisted in the preliminary genetic identification some of the strains. Lastly, we thank Stephanie Held for help in formatting and editing the manuscript.

Data Availability Statement: The DNA sequencing datasets generated for this study can be found in the GenBank database, under accession numbers MH746823-MH746869.

Conflicts of Interest: The authors declare no conflict of interest.

\section{References}

1. Antón, J.; Llobet-Brossa, E.; Rodriguez-Valera, F.; Amann, R. Fluorescence in situ hybridization analysis of the prokaryotic community inhabiting crystallizer ponds. Environ. Microbiol. 1999, 1, 517-523. [CrossRef] [PubMed]

2. McGenity, T.J.; Gemmell, R.T.; Grant, W.D.; Stan-Lotter, H. Origins of halophilic microorganisms in ancient salt deposits. Environ. Microbiol. 2000, 2, 243-250. [CrossRef] [PubMed]

3. Ghai, R.; Pašić, L.; Fernández, A.B.; Martin-Cuadrado, A.B.; Mizuno, C.M.; McMahon, K.D.; Papke, R.T.; Stepanauskas, R.; Rodriguez-Brito, B.; Rohwer, F.; et al. New abundant microbial groups in aquatic hypersaline environments. Sci. Rep. 2011, 1, 135. [CrossRef] [PubMed]

4. Andrei, A.-Ş.; Banciu, H.L.; Oren, A. Living with salt: Metabolic and phylogenetic diversity of archaea inhabiting saline ecosystems. FEMS Microbiol. Lett. 2012, 330, 1-9. [CrossRef] [PubMed]

5. Almeida-Dalmet, S.; Sikaroodi, M.; Gillevet, P.M.; Litchfield, C.D.; Baxter, B.K. Temporal study of the microbial diversity of the North Arm of Great Salt Lake, Utah, US. Microorganisms 2015, 3, 310-326. [CrossRef] [PubMed]

6. Fendrihan, S.; Dornmayr-Pfaffenhuemer, M.; Gerbl, F.W.; Holzinger, A.; Grösbacher, M.; Briza, P.; Erler, A.; Gruber, C.; Plätzer, K.; Stan-Lotter, H. Spherical particles of halophilic archaea correlate with exposure to low water activity-implications for microbial survival in fluid inclusions of ancient halite. Geobiology 2012, 10, 424-433. [CrossRef] [PubMed]

7. Norton, C.F.; Grant, W.D. Survival of Halobacteria within fluid inclusions in salt crystals. J. Gen. Microbiol. 1988, 134, 1365-1373. [CrossRef]

8. Norton, C.F.; McGenity, T.J.; Grant, W.D. Archaeal halophiles (halobacteria) from two British salt mines. Microbiology 1993, 139, 1077-1081. [CrossRef]

9. Denner, E.B.M.; McGenity, T.J.; Busse, H.-J.; Grant, W.D.; Wanner, G.; Stan-Lotter, H. Halococcus salifodinae sp.nov., an archaeal isolate from an Austrian salt mine. Int. J. Syst. Evol. Microbiol. 1994, 44, 774-780.

10. Grant, W.D.; Gemmell, R.T.; McGenity, T.J. Halobacteria: The evidence for longevity. Extremophiles 1998, 2 , 279-287. [CrossRef] [PubMed]

11. Stan-Lotter, H.; McGenity, T.J.; Legat, A.; Denner, E.B.; Glaser, K.; Stetter, K.O.; Wanner, G. Very similar strains of Halococcus salifodinae are found in geographically separated Permo-Triassic salt deposits. Microbiology 1999, 145, 3565-3574. [CrossRef] [PubMed]

12. Vreeland, R.H.; Rosenzweig, W.D.; Powers, D.W. Isolation of a 250 million-year-old halotolerant bacterium from a primary salt crystal. Nature 2000, 407, 897-900. [CrossRef] [PubMed] 
13. Stan-Lotter, H.; Pfaffenhuemer, M.; Legat, A.; Busse, H.-J.; Radax, C.; Gruber, C. Halococcus dombrowskii sp. nov., an archaeal isolate from a Permo-Triassic alpine salt deposit. Int. J. Syst. Bacteriol. 2002, 52, 1807-1814.

14. Kminek, G.; Bada, J.L.; Pogliano, K.; Ward, J.F. Radiation-Dependent Limit for the Viability of Bacterial Spores in Halite Fluid Inclusions and on Mars. Radiat. Res. 2003, 159, 722-729. [CrossRef]

15. Mormile, M.R.; Biesen, M.A.; Gutierrez, M.C.; Ventosa, A.; Pavlovich, J.B.; Onstott, T.C.; Fredrickson, J.K. Isolation of Halobacterium salinarum retrieved directly from halite brine inclusions. Environ. Microbiol. 2003, 5, 1094-1102. [CrossRef] [PubMed]

16. Gruber, C.; Legat, A.; Pfaffenhuemer, M.; Radax, C.; Weidler, G.; Busse, H.J.; Stan-Lotter, H. Halobacterium noricense sp. nov., an archaeal isolate from a bore core of an alpine Permian salt deposit, classification of Halobacterium sp. NRC-1 as a strain of H. salinarum and emended description of H. salinarum. Extremophiles 2004, 8, 431-439. [CrossRef] [PubMed]

17. Park, J.S.; Vreeland, R.H.; Cho, B.C.; Lowenstein, T.K.; Timofeeff, M.N.; Rosenzweig, W.D. Haloarchaeal diversity in 23, 121 and 419 MYA salts. Geobiology 2009, 7, 515-523. [CrossRef] [PubMed]

18. Schubert, B.A.; Lowenstein, T.K.; Timofeeff, M.N. Microscopic identification of prokaryotes in modern and ancient halite, Saline Valley and Death Valley, California. Astrobiology 2009, 9, 467-482. [CrossRef] [PubMed]

19. Schubert, B.A.; Lowenstein, T.K.; Timofeeff, M.N.; Parker, M.A. Halophilic Archaea cultured from ancient halite, Death Valley, California. Environ. Microbiol. 2010, 12, 440-454. [CrossRef] [PubMed]

20. Lowenstein, T.K.; Schubert, B.A.; Timofeeff, M.N. Microbial communities in fluid inclusions and long-term survival in halite. Geol. Soc. Am. Today 2011, 21, 4-9. [CrossRef]

21. Sankaranarayanan, K.; Timofeeff, M.N.; Spathis, R.; Lowenstein, T.K.; Lum, J.K. Ancient Microbes from Halite Fluid Inclusions: Optimized Surface Sterilization and DNA Extraction. PLoS ONE 2011, 6, e20683. [CrossRef] [PubMed]

22. Mancinelli, R.L.; White, M.R.; Rothschild, L.J. Biopan-survival I: Exposure of the osmophiles Synechococcus sp. (Nageli) and Haloarcula sp. to the space environment. Adv. Space Res. 1998, 22, 327-334. [CrossRef]

23. Mancinelli, R.L. The effect of the space environment on the survival of Halorubrum chaoviator and Synechococcus (Nägeli): Data from the Space Experiment OSMO on EXPOSE-R. Int. J. Astrobiol. 2015, 14, 123-128. [CrossRef]

24. Rabbow, E.; Horneck, G.; Rettberg, P.; Schott, J.U.; Panitz, C.; L'Afflitto, A.; von Heise-Rotenburg, R.; Willnecker, R.; Baglioni, P.; Hatton, J.; et al. EXPOSE, an astrobiological exposure facility on the international space station-from proposal to flight. Orig. Life Evol. Biospheres 2009, 39, 581-598. [CrossRef] [PubMed]

25. Jones, D.L.; Baxter, B.K. DNA Repair and Photoprotection: Mechanisms of Overcoming Environmental Ultraviolet Radiation Exposure in Halophilic Archaea. Front. Microbiol. 2017, 8, 1882. [CrossRef] [PubMed]

26. da Costa, M.S.; Santos, H.; Galinski, E.A. An overview of the role and diversity of compatible solutes in bacteria and archaea. Adv. Biochem. Eng. Biotechnol. 1998, 61, 117-153. [PubMed]

27. Roberts, M.F. Organic compatible solutes of halotolerant and halophilic microorganisms. Saline Syst. 2005, 1, 1-30. [CrossRef] [PubMed]

28. Baxter, B.K.; Eddington, B.; Riddle, M.R.; Webster, T.N.; Avery, B.J. Great Salt Lake Halophilic Microorganisms as Models for Astrobiology: Evidence for Desiccation Tolerance and Ultraviolet Radiation Resistance. In Proceedings of the SPIE 6694, Instruments, Methods, and Missions for Astrobiology X, 669415, Bellingham, WA, USA, 3 October 2007.

29. Kish, A.; DiRuggiero, J. DNA replication and repair in Halophiles. In Advances in Understanding the Biology of Halophilic Microorganisms; Vreeland, H.R., Ed.; Springer: Dordrecht, The Netherlands, 2012; pp. 163-198, ISBN 978-94-007-5538-3.

30. Jones, D.L.; Baxter, B.K. Bipyrimidine Signatures as a Photoprotective Genome Strategy in G+ C-rich Halophilic Archaea. Life 2016, 6, 37. [CrossRef] [PubMed]

31. Oren, A. Taxonomy of halophilic Archaea: Current status and future challenges. Extremophiles 2014, 18, 825-834. [CrossRef] [PubMed]

32. Benlloch, S.; Martinez-Murcia, A.J.; Rodriguez-Valera, F. Sequencing of bacterial and archaeal 16S rRNA genes directly amplified from a hypersaline environment. Syst. Appl. Microbiol. 1995, 18, 574-581. [CrossRef]

33. Benlloch, S.; Acinas, S.G.; Antón, J.; Lopez-Lopez, A.; Luz, S.P.; Rodríguez-Valera, F. Archaeal biodiversity in crystallizer ponds from a solar saltern: Culture versus PCR. Microb. Ecol. 2001, 41, 12-19. [PubMed] 
34. McGenity, T.J.; Grant, W.D. Transfer of Halobacterium saccharovorum, Halobacterium sodomense, Halobacterium trapanicum NRC 34021 and Halobacterium lacusprofundi to the genus Halorubrum gen. nov., as Halorubrum saccharovorum comb. nov., Halorubrum sodomense comb. nov., Halorubrum trapanicum comb. nov., and Halorubrum lacusprofundi comb. nov. Syst. Appl. Microbiol. 1995, 18, 237-243.

35. Papke, R.T.; Koenig, J.E.; Rodríguez-Valera, F.; Doolittle, W.F. Frequent recombination in a saltern population of Halorubrum. Science 2004, 306, 1928-1929. [PubMed]

36. Mancinelli, R.L.; Landheim, R.; Sanchez-Porro, C.; Dornmayr-Pfaffenhuemer, M.; Gruber, C.; Legat, A.; Ventosa, A.; Radax, C.; Ihara, K.; White, M.R.; et al. Halorubrum chaoviator sp. nov., a haloarchaeon isolated from sea salt in Baja California, Mexico, Western Australia and Naxos, Greece. Int. J. Syst. Evol. Microbiol. 2009, 59, 1908-1913. [CrossRef] [PubMed]

37. Chen, S.X.; Zhao, Z.W.; Zeng, C.; Yang, Z.L. Phylogenetic analysis of 16 S rRNA gene reveals high species diversity of Halorubrum in China. Afr. J. Microbiol. Res. 2013, 7, 3009-3017.

38. Oren, A.; Hallsworth, J.E. Microbial weeds in hypersaline habitats: The enigma of the weed-like Haloferax mediterranei. FEMS Microbiol. Lett. 2014, 359, 134-142. [CrossRef] [PubMed]

39. Papke, R.T.; Zhaxybayeva, O.; Feil, E.J.; Sommerfeld, K.; Muise, D.; Doolittle, W.F. Searching for species in haloarchaea. Proc. Natl. Acad. Sci. USA 2007, 104, 14092-14097. [CrossRef] [PubMed]

40. Fullmer, M.S.; Soucy, S.M.; Swithers, K.S.; Makkay, A.M.; Wheeler, R.; Ventosa, A.; Gogarten, J.P.; Papke, R.T. Population and genomic analysis of the genus Halorubrum. Front. Microbiol. 2014, 5, 140. [CrossRef] [PubMed]

41. Ram Mohan, N.; Fullmer, M.S.; Makkay, A.M.; Wheeler, R.; Ventosa, A.; Naor, A.; Gogarten, J.P.; Papke, R.T. Evidence from phylogenetic and genome fingerprinting analyses suggests rapidly changing variation in Halorubrum and Haloarcula populations. Front. Microbiol. 2014, 5, 143. [CrossRef] [PubMed]

42. Oren, A.; Ginzburg, M.; Ginzburg, B.Z.; Hochstein, L.I.; Volcani, B.E. Haloarcula marismortui (Volcani) sp. nov., nom. rev., an extremely halophilic bacterium from the Dead Sea. Int. J. Syst. Evol. Microbiol. 1990, 40, 209-210. [CrossRef] [PubMed]

43. Takashina, T.; Hamamoto, T.; Otozai, K.; Grant, W.D.; Horikoshi, K. Haloarcula japonica sp. nov., a new triangular halophilic archaebacterium. Syst. Appl. Microbiol. 1990, 13, 177-181. [CrossRef]

44. Juez, G.; Rodriguez-Valera, F.; Ventosa, A.; Kushner, D.J. Haloarcula hispanica spec. nov. and Haloferax gibbonsii spec, nov., two new species of extremely halophilic archaebacteria. Syst. Appl. Microbial. 1986, 8, 75-79. [CrossRef]

45. Almeida-Dalmet, S.; Litchfield, C.D.; Gillevet, P.; Baxter, B.K. Differential gene expression in response to salinity and temperature in a Haloarcula Strain from Great Salt Lake, Utah. Genes 2018, 9, 52. [CrossRef] [PubMed]

46. Riddle, M.R.; Baxter, B.K.; Avery, B.J. Molecular identification of microorganisms associated with the brine shrimp Artemia franciscana. Aquat. Biosyst. 2013, 9, 1-11. [CrossRef] [PubMed]

47. Keck, W.; Hassibe, W. The Great Salt Lake; U.S. Geological Survey: Reston, VA, USA, 1978; pp. 1-16.

48. Bellrose, F.C. Ducks, Geese, and Swans of North America; Stackpole Books: Harrisburg, PA, USA, 1980; ISBN 978-1421407517.

49. Oring, L.W.; Neel, L.; Oring, K.E. Intermountain West Regional Shorebird Plan. Available online: https: / / www.shorebirdplan.org/wp-content/uploads/2013/01/IMWEST4.pdf (accessed on 3 October 2018).

50. Paul, D.S.; Manning, A.E. Great Salt Lake Waterbird Survey Five-Year Report (1997-2001); Publication Number 08-38; Utah Division of Wildlife Resources: Salt Lake City, UT, USA, 2002.

51. Aldrich, T.W.; Paul, D.S. Avian ecology of Great Salt Lake. In Great Salt Lake: An Overview of Change; Gwynn, J.W., Ed.; Utah Department of Natural Resources: Salt Lake City, Utah, USA, 2002; pp. 343-374, ISBN 1557916675.

52. Neill, J.; Leite, B.; Gonzales, J.; Sanchez, K.; Luft, J. 2015 Great Salt Lake Eared Grebe Aerial Photo Survey: Annual Report; Utah Division of Wildlife Resources: Salt Lake City, UT, USA, 2016.

53. Packard, A.S., Jr. On insects inhabiting salt water. Am. J. Sci. 1871, 3, 100-110. [CrossRef]

54. Aldrich, J.M. The biology of some western species of the dipterous genus Ephydra. J. N. Y. Entomol. Soc. 1912, 20,77-102.

55. Collins, N. Population ecology of Ephydra cinerea Jones (Diptera: Ephydridae), the only benthic metazoan of the Great Salt Lake, USA. Hydrobiologia 1980, 68, 99-112. [CrossRef] 
56. Wurtsbaugh, W.A.; Gliwicz, Z.M. Limnological control of brine shrimp population dynamics and cyst production in the Great Salt Lake, Utah. Hydrobiologia 2001, 466, 119-132. [CrossRef]

57. Roberts, A.J. Avian diets in a saline ecosystem: Great Salt Lake, Utah, USA. Hum. Wildl. Interact. $2013,7,15$.

58. Ochsenreiter, T.; Pfeifer, F.; Schleper, C. Diversity of Archaea in hypersaline environments characterized by molecular-phylogenetic and cultivation studies. Extremophiles 2002, 6, 267-274. [CrossRef] [PubMed]

59. Gill, F.B. Migration. In Ornithology, 2nd ed.; W.H. Freeman and Co.: New York, NY, USA, 1995; pp. $287-309$.

60. Hubálek, Z. An annotated checklist of pathogenic microorganisms associated with migratory birds. J. Wildl. Dis. 2004, 40, 639-659. [CrossRef] [PubMed]

61. Georgopoulou, I.; Tsiouris, V. The potential role of migratory birds in the transmission of zoonoses. Vet. Ital. 2008, 44, 671-677. [PubMed]

62. Warner, G.M.; French, D.W. Dissemination of fungi by migratory birds: Survival and recovery of fungi from birds. Can. J. Bot. 1970, 48, 907-910. [CrossRef]

63. Johnson, M.L.; Speare, R. Possible modes of dissemination of the amphibian chytrid Batrachochytrium dendrobatidis in the environment. Dis. Aquat. Org. 2005, 65, 181-186. [CrossRef] [PubMed]

64. Oh, D.; Porter, K.; Russ, B.; Burns, D.; Dyall-Smith, M. Diversity of Haloquadratum and other haloarchaea in three, geographically distant, Australian saltern crystallizer ponds. Extremophiles 2010, 14, 161-169. [CrossRef] [PubMed]

65. Baricz, A.; Cristea, A.; Muntean, V.; Teodosiu, G.; Andrei, A.Ş.; Molnár, I.; Alexe, M.; Rakosy-Tican, E.; Banciu, H.L. Culturable diversity of aerobic halophilic archaea (Fam. Halobacteriaceae) from hypersaline, meromictic Transylvanian lakes. Extremophiles 2015, 19, 525-537. [CrossRef] [PubMed]

66. Brito-Echeverría, J.; López-López, A.; Yarza, P.; Antón, J.; Rosselló-Mora, R. Occurrence of Halococcus spp. in the nostrils salt glands of the seabird Calonectris diomedea. Extremophiles 2009, 13, 557-565. [CrossRef] [PubMed]

67. Yim, K.J.; Kwon, J.; Cha, I.T.; Oh, K.S.; Song, H.S.; Lee, H.W.; Rhee, J.K.; Song, E.J.; Rho, J.R.; Seo, M.L.; et al. Occurrence of viable, red-pigmented haloarchaea in the plumage of captive flamingoes. Sci. Rep. 2015, 5, 16425. [CrossRef] [PubMed]

68. Dyall-Smith, M. The Halohandbook, Version 7.2. 2009. Available online: http://www.haloarchaea.com/ resources/halohandbook/ (accessed on 3 October 2018).

69. Litchfield, C.D.; Sikaroodi, M.; Gillevet, P.M. Characterization of natural communities of halophilic microorganisms. Methods Microbiol. 2006, 35, 513-533.

70. Mankin, A.S.; Kagramanova, V.K.; Teterina, N.L.; Rubtsov, P.M.; Belova, E.N.; Kopylov, A.M.; Baratova, L.A.; Bogdanov, A.A. The nucleotide sequence of the gene coding for the 16S rRNA from the archaebacterium Halobacterium halobium. Gene 1985, 37, 181-189. [CrossRef]

71. Martinez-Murcia, A.J.; Acinas, S.G.; Rodriguez-Valera, F. Evaluation of prokaryotic diversity by restrictase digestion of $16 \mathrm{~S}$ rDNA directly amplified from hypersaline environments. FEMS Microbiol. Ecol. 1995, 17, 247-255. [CrossRef]

72. DeLong, E.F.; Wu, K.Y.; Prézelin, B.B.; Jovine, R.V. High abundance of Archaea in Antarctic marine picoplankton. Nature 1994, 371, 695. [CrossRef] [PubMed]

73. National Library of Medicine, National Center for Biotechnology Information. Available online: https: / / blast.ncbi.nlm.nih.gov/Blast.cgi?PAGE_TYPE=BlastSearch (accessed on 15 April 2018).

74. Peel, M.C.; Finlayson, B.L.; McMahon, T.A. Updated world map of the Köppen-Geiger climate classification. Hydrol. Earth Syst. Sci. Discuss. 2007, 4, 439-473. [CrossRef]

75. Climate-Data. Available online: https:/ / en.climate-data.org/ (accessed on 17 March 2018).

76. State of Utah. Pelican Management Act. Available online: https://le.utah.gov/xcode/Title23/Chapter21A/ C23-21a_1800010118000101.pdf (accessed on 3 October 2018).

77. Great Salt Lake Institute PELIcam. Available online: https:/ /westminstercollege.edu/campus-life/centersand-institutes/great-salt-lake-institute/pelicam (accessed on 24 May 2018).

78. Neill, J.; Brewerton, A.; Davidson, M.; Leite, B.; Gonzalez, J.; Sanchez, K. 2016 American White Pelican Census, Gunnison Island Utah; Utah Division of Wildlife Resources: Salt Lake City, UT, USA, 2018; Unpublished report; $23 \mathrm{p}$.

79. Knopf, F.L. Spatial and temporal aspects of colonial nesting of White Pelicans. Condor 1979, 81, $353-363$. [CrossRef] 
80. State of Utah, Division of Wildlife Resources PeliTrack. Available online: https://wildlife.utah.gov/pelican webmap/ (accessed on 13 July 2018).

81. Pal, K.K.; Dey, R.; Thomas, M.; Dave, S.R.; Ghorai, S. Diversity of Archaebacteria of Natural and Man-Made Salt Pan of Kachchh Region of Gujarat. Direct Submission to GenBank; 2011. Available online: https: / / www.ncbi.nlm.nih.gov/nuccore/JF802147.1?report=GenBank (accessed on 22 May 2018).

82. Yang, Y.; Cui, H.L.; Zhou, P.J.; Liu, S.J. Haloarcula amylolytica sp. nov., an extremely halophilic archaeon isolated from Aibi salt lake in Xin-Jiang, China. Int. J. Syst. Evol. Microbiol. 2007, 57, 103-106. [CrossRef] [PubMed]

83. Yadav, A.N.; Sachan, S.G.; Verma, P.; Kaushik, R.; Saxena, A.K. Diversity of Psychrotolerant Archaea from Cold Desert of Leh-Ladakh and Rohtang Pass (India). Direct Submission to GenBank; 2013. Available online: https: / / www.ncbi.nlm.nih.gov/nuccore/KF650693.1?report=GenBank (accessed on 22 May 2018).

84. Ihara, K.; Watanabe, S.; Tamura, T. Haloarcula argentinensis sp. nov. and Haloarcula mukohataei sp. nov., two new extremely halophilic archaea collected in Argentina. Int. J. Syst. Evol. Microbiol. 1997, 47, 73-77. [CrossRef] [PubMed]

85. Fukushima, T.; Usami, R.; Kamekura, M. A traditional Japanese-style salt field is a niche for haloarchaeal strains that can survive in $0.5 \%$ salt solution. Saline Syst. 2007, 3, 2. [CrossRef] [PubMed]

86. Thombre, R.S.; Shinde, V.D.; Oke, R.S.; Dhar, S.K.; Shouche, Y.S. Biology and survival of extremely halophilic archaeon Haloarcula marismortui RR12 isolated from Mumbai salterns, India in response to salinity stress. Sci. Rep. 2016, 6, 25642. [CrossRef] [PubMed]

87. Baliga, N.S.; Bonneau, R.; Facciotti, M.T.; Pan, M.; Glusman, G.; Deutsch, E.W.; Shannon, P.; Chiu, Y.; Weng, R.S.; Gan, R.R.; et al. Genome sequence of Haloarcula marismortui: A halophilic archaeon from the Dead Sea. Genome Res. 2004, 14, 2221-2234. [CrossRef] [PubMed]

88. Luque, R.; González-Domenech, C.M.; Llamas, I.; Quesada, E.; Béjar, V. Diversity of culturable halophilic archaea isolated from Rambla Salada, Murcia (Spain). Extremophiles 2012, 16, 205-213. [CrossRef] [PubMed]

89. Oren, A.; Ventosa, A.; Gutiérrez, M.C.; Kamekura, M. Haloarcula quadrata sp. nov., a square, motile archaeon isolated from a brine pool in Sinai (Egypt). Int. J. Syst. Evol. Microbiol. 1999, 49, 1149-1155. [CrossRef] [PubMed]

90. Namwong, S.; Tanasupawat, S.; Kudo, T.; Itoh, T. Haloarcula salaria sp. nov. and Haloarcula tradensis sp. nov., isolated from salt in Thai fish sauce. Int. J. Syst. Evol. Microbiol. 2011, 61, 231-236. [CrossRef] [PubMed]

91. Akolkar, AV.; Deshpande, GM.; Desai, A.J. Isolation and Characterization of Halophilic Archaea from Indian Salterns. Direct Submission to GenBank; 2006. Available online: https:/ /www.ncbi.nlm.nih.gov/nuccore/ DQ899739.1? report=GenBank (accessed on 22 May 2018).

92. de Lourdes Moreno, M.; García, M.T.; Ventosa, A.; Mellado, E. Characterization of Salicola sp. IC10, a lipase-and protease-producing extreme halophile. FEMS Microbiol. Ecol. 2009, 68, 59-71. [CrossRef] [PubMed]

93. Kebbouche-Gana, S.; Gana, M.L.; Khemili, S.; Fazouane-Naimi, F.; Bouanane, N.A.; Penninckx, M.; Hacene, H. Isolation and characterization of halophilic Archaea able to produce biosurfactants. J. Ind. Microbiol. Biotechnol. 2009, 36, 727-738. [CrossRef] [PubMed]

94. Nercessian, D.; Di Meglio, L.; De Castro, R.; Paggi, R. Exploring the multiple biotechnological potential of halophilic microorganisms isolated from two Argentinean salterns. Extremophiles 2015, 19, 1133-1143. [CrossRef] [PubMed]

95. Liu, H.; Wu, Z.; Li, M.; Zhang, F.; Zheng, H.; Han, J.; Liu, J.; Zhou, J.; Wang, S.; Xiang, H. Complete genome sequence of Haloarcula hispanica, a model haloarchaeon for studying genetics, metabolism, and virus-host interaction. J. Bacteriol. 2011, 193, 6086-6087. [CrossRef] [PubMed]

96. Javor, B.; Requadt, C.; Stoeckenius, W. Box-shaped halophilic bacteria. J. Bacteriol. 1982, 151, $1532-1542$. [PubMed]

97. Gonzalez, C.; Gutierrez, C.; Ramirez, C. Halobacterium vallismortis sp. nov. An amylolytic and carbohydrate-metabolizing, extremely halophilic bacterium. Can. J. Microbiol. 1978, 24, 710-715. [CrossRef] [PubMed]

98. Xu, X.W.; Wu, Y.H.; Zhang, H.B.; Wu, M. Halorubrum arcis sp. nov., an extremely halophilic archaeon isolated from a saline lake on the Qinghai-Tibet Plateau, China. Int. J. Syst. Evol. Microbiol. 2007, 57, 1069-1072. [CrossRef] [PubMed] 
99. Viver, T.; Cifuentes, A.; Díaz, S.; Rodríguez-Valdecantos, G.; González, B.; Antón, J.; Rosselló-Móra, R. Diversity of extremely halophilic cultivable prokaryotes in Mediterranean, Atlantic and Pacific solar salterns: Evidence that unexplored sites constitute sources of cultivable novelty. Syst. Appl. Microbiol. 2015, 38, 266-275. [CrossRef] [PubMed]

100. Pesenti, P.T.; Sikaroodi, M.; Gillevet, P.M.; Sanchez-Porro, C.; Ventosa, A.; Litchfield, C.D. Halorubrum californiense sp. nov., an extreme archaeal halophile isolated from a crystallizer pond at a solar salt plant in California, USA. Int. J. Syst. Evol. Microbiol. 2008, 58, 2710-2715. [CrossRef] [PubMed]

101. Baati, H.; Guermazi, S.; Gharsallah, N.; Sghir, A.; Ammar, E. Novel prokaryotic diversity in sediments of Tunisian multipond solar saltern. Res. Microbiol. 2010, 161, 573-582. [CrossRef] [PubMed]

102. Boujelben, I.; Martínez-García, M.; van Pelt, J.; Maalej, S. Diversity of cultivable halophilic archaea and bacteria from superficial hypersaline sediments of Tunisian solar salterns. Antonie Leeuwenhoek 2014, 106, 675-692. [CrossRef] [PubMed]

103. Dilbar, T.; Yinipigul, H. Isolation and phylogenetic analysis of haloalkalophilic bacteria in the black lake of Yuli County in Xinjiang. Microbiol. Bull. 2016, 43, 2601-2608.

104. Castillo, A.M.; Gutiérrez, M.C.; Kamekura, M.; Xue, Y.; Ma, Y.; Cowan, D.A.; Jones, B.E.; Grant, W.D.; Ventosa, A. Halorubrum ejinorense sp. nov., isolated from Lake Ejinor, Inner Mongolia, China. Int. J. Syst. Evol. Microb. 2007, 757, 2538-2542. [CrossRef] [PubMed]

105. Kharroub, K.; Quesada, T.; Ferrer, R.; Fuentes, S.; Aguilera, M.; Boulahrouf, A.; Ramos-Cormenzana, A.; Monteoliva-Sanchez, M. Halorubrum ezzemoulense sp. nov., a halophilic archaeon isolated from Ezzemoul sabkha, Algeria. Int. J. Syst. Evol. Microbiol. 2006, 56, 1583-1588. [CrossRef] [PubMed]

106. Dammak, D.F.; Smaoui, S.M.; Ghanmi, F.; Boujelben, I.; Maalej, S. Characterization of halo-alkaline and thermostable protease from Halorubrum ezzemoulense strain ETR14 isolated from Sfax solar saltern in Tunisia. J. Basic Microbiol. 2016, 56, 337-346. [CrossRef] [PubMed]

107. Cui, H.L.; Lin, Z.Y.; Dong, Y.; Zhou, P.J.; Liu, S.J. Halorubrum litoreum sp. nov., an extremely halophilic archaeon from a solar saltern. Int. J. Syst. Evol. Microbiol. 2007, 57, 2204-2206. [CrossRef] [PubMed]

108. Gonzalez, R.O.; Higa, L.H.; Cutrullis, R.A.; Bilen, M.; Morelli, I.; Roncaglia, D.I.; Corral, R.S.; Morilla, M.J.; Petray, P.B.; Romero, E.L. Archaeosomes made of Halorubrum tebenquichense total polar lipids: A new source of adjuvancy. BMC Biotechnol. 2009, 9, 71. [CrossRef] [PubMed]

109. Lizama, C.; Monteoliva-Sánchez, M.; Suárez-García, A.; Roselló-Mora, R.; Aguilera, M.; Campos, V.; Ramos-Cormenzana, A. Halorubrum tebenquichense sp. nov., a novel halophilic archaeon isolated from the Atacama Saltern, Chile. Int. J. Syst. Evol. Microbiol. 2002, 52, 149-155. [CrossRef] [PubMed]

110. Zvyagintseva, I.S.; Tarasov, A.L. Extreme halophilic bacteria from saline soils. Mikrobiologiya 1988, 56, 839-844. (In Russian)

111. Ventosa, A.; Gutierrez, M.C.; Kamekura, M.; Zvyagintseva, I.S.; Oren, A. Taxonomic study of Halorubrum distributum and proposal of Halorubrum terrestre sp. nov. Int. J. Syst. Evol. Microbiol. 2004, 54, 389-392. [CrossRef] [PubMed]

112. Feng, J.; Zhou, P.J.; Liu, S.J. Halorubrum xinjiangense sp. nov., a novel halophile isolated from saline lakes in China. Int. J. Syst. Evol. Microbiol. 2004, 54, 1789-1791. [CrossRef] [PubMed]

113. Atanasova, N.S.; Roine, E.; Oren, A.; Bamford, D.H.; Oksanen, H.M. Global network of specific virus-host interactions in hypersaline environments. Environ. Microbiol. 2012, 14, 426-440. [CrossRef] [PubMed]

114. Atanasova, N.S.; Demina, T.A.; Buivydas, A.; Bamford, D.H.; Oksanen, H.M. Archaeal viruses multiply: Temporal screening in a solar saltern. Viruses 2015, 7, 1902-1926. [CrossRef] [PubMed]

115. China, S. Species Diversity of Yunnan Salt Mine, China. Direct Submission to GenBank; 2016. Available online: https: / / www.ncbi.nlm.nih.gov/nuccore/KX376714.1 (accessed on 22 May 2018).

116. Ma, Y.; Galinski, E.A.; Grant, W.D.; Oren, A.; Ventosa, A. Halophiles 2010: Life in Saline Environments. Appl. Environ. Microbiol. 2010, 76, 6971-6981. [CrossRef] [PubMed]

117. Crosman, E.T.; Horel, J.D. MODIS-derived surface temperature of the Great Salt Lake. Remote Sens. Environ. 2009, 113, 73-81. [CrossRef]

118. Post, F.J. The microbial ecology of the Great Salt Lake. Microbiol Ecol. 1977, 3, 143-165. [CrossRef] [PubMed]

119. Baas-Becking, L.G.M. Geobiologie of Inleiding tot the Milieukunde; W. P. van Stockum and Zoon: The Hague, The Netherlands, 1934; ISBN 44189670.

120. Finlay, B.J. Global dispersal of free-living microbial eukaryote species. Science 2002, 296, 1061-1063. [CrossRef] [PubMed] 
121. Whitfield, J. Biogeography: Is everything everywhere? Science 2005, 310, 960-962. [CrossRef] [PubMed]

122. Martiny, J.B.; Bohannan, B.J.; Brown, J.H.; Colwell, R.K.; Fuhrman, J.A.; Green, J.L.; Horner-Devine, M.C.; Kane, M.; Krumins, J.A.; Kuske, C.R.; et al. Microbial biogeography: Putting microorganisms on the map. Nat. Rev. Microbiol. 2006, 4, 102-112. [CrossRef] [PubMed]

123. Ryšánek, D.; Hrčková, K.; Škaloud, P. Global ubiquity and local endemism of free-living terrestrial protists: Phylogeographic assessment of the streptophyte alga Klebsormidium. Environ. Microbiol. 2014, 17, 689-698. [CrossRef] [PubMed]

124. Van der Gast, C.J. Microbial biogeography: The end of the ubiquitous dispersal hypothesis? Environ. Microbiol. 2015, 17, 544-546. [CrossRef] [PubMed]

125. Pagaling, E.; Wang, H.; Venables, M.; Wallace, A.; Grant, W.D.; Cowan, D.A.; Jones, B.E.; Ma, Y.; Ventosa, A.; Heaphy, S. Microbial biogeography of six salt lakes in Inner Mongolia, China, and a salt lake in Argentina. Appl. Environ. Microbiol. 2009, 75, 5750-5760. [CrossRef] [PubMed]

126. Schiaffino, M.R.; Unrein, F.; Gasol, J.M.; Massana, R.; Balague, V.; Izaguirre, I. Bacterial community structure in a latitudinal gradient of lakes: The roles of spatial versus environmental factors. Freshw. Biol. 2011, 56, 1973-1991. [CrossRef]

127. Bowers, K.J.; Wiegel, J. Temperature and pH optima of extremely halophilic archaea: A mini-review. Extremophiles 2011, 15, 119-128. [CrossRef] [PubMed]

128. Siroosi, M.; Amoozegar, M.A.; Khajeh, K.; Fazeli, M.; Rezaei, M.H. Purification and characterization of a novel extracellular halophilic and organic solvent-tolerant amylopullulanase from the haloarchaeon, Halorubrum sp. strain Ha25. Extremophiles 2014, 18, 25-33. [CrossRef] [PubMed]

129. Papke, R.T.; Ward, D.M. The importance of physical isolation to microbial diversification. FEMS Microbiol. Ecol. 2005, 48, 293-303. [CrossRef] [PubMed]

130. Rossello-Mora, R.; Lucio, M.; Peña, A.; Brito-Echeverría, J.; Lopez-Lopez, A.; Valens-Vadell, M.; Frommberger, M.; Antón, J.; Schmitt-Kopplin, P. Metabolic evidence for biogeographic isolation of the extremophilic bacterium Salinibacter ruber. ISME J. 2008, 2, 242. [CrossRef] [PubMed]

131. Woese, C.R. Bacterial evolution. Microbiol. Rev. 1987, 51, 221. [PubMed]

132. Hedlund, B.P.; Staley, J.T. Microbial endemism and biogeography. In Microbial Diversity and Bioprospecting; Bull, A.T., Ed.; American Society for Microbiology Press: Washington, DC, USA, 2004; pp. 225-231, ISBN 1-55581-267-8.

133. Mylvaganam, S.; Dennis, P.P. Sequence heterogeneity between the two genes encoding $16 \mathrm{~S}$ rRNA from the halophilic archaebacterium Haloarcula marismortui. Genetics 1992, 130, 399-410. [PubMed]

134. Boucher, Y.; Douady, C.J.; Sharma, A.K.; Kamekura, M.; Doolittle, W.F. Intragenomic heterogeneity and intergenomic recombination among haloarchaeal rRNA genes. J. Bacteriol. 2004, 186, 3980-3990. [CrossRef] [PubMed]

135. Cui, H.L.; Zhou, P.J.; Oren, A.; Liu, S.J. Intraspecific polymorphism of $16 \mathrm{~S}$ rRNA genes in two halophilic archaeal genera. Haloarcula and Halomicrobium. Extremophiles 2009, 13, 31-37. [CrossRef] [PubMed]

136. Sun, D.L.; Jiang, X.; Wu, Q.L.; Zhou, N.Y. Intragenomic heterogeneity of $16 \mathrm{~S}$ rRNA genes causes overestimation of prokaryotic diversity. Appl. Environ. Microbiol. 2013, 79, 5962-5969. [CrossRef] [PubMed]

137. Kim, M.; Oh, H.S.; Park, S.C.; Chun, J. Towards a taxonomic coherence between average nucleotide identity and 16S rRNA gene sequence similarity for species demarcation of prokaryotes. Int. J. Syst. Evol. Microbiol. 2014, 64, 346-351. [CrossRef] [PubMed]

138. Head, I.M.; Saunders, J.R.; Pickup, R.W. Microbial evolution, diversity, and ecology: A decade of ribosomal RNA analysis of uncultivated microorganisms. Microb. Ecol. 1998, 35, 1-21. [CrossRef] [PubMed]

139. Pyatibratov, M.G.; Beznosov, S.N.; Rachel, R.; Tiktopulo, E.I.; Surin, A.K.; Syutkin, A.S.; Fedorov, O.V. Alternative flagellar filament types in the haloarchaeon Haloarcula marismortui. Can. J. Microbiol. 2008, 54, 835-844. [CrossRef] [PubMed]

140. Oren, A. The enigma of square and triangular halophilic Archaea. In Enigmatic Microorganisms and Life in Extreme Environments; Seckbach, J., Ed.; Springer: Dordrecht, The Netherlands, 1999; pp. 337-355, ISBN 978-94-011-4838-2.

141. Lin, Y.C.; Fu, H.Y.; Yang, C.S. Phototaxis of Haloarcula marismortui revealed through a novel microbial motion analysis algorithm. Photochem. Photobiol. 2010, 86, 1084-1090. [CrossRef] [PubMed]

142. Rodriguez-Valera, F.; Ruiz-Berraquero, F.; Ramos-Cormenzana, A. Isolation of extreme halophiles from seawater. Appl. Environ. Microbiol. 1979, 38, 164-165. [PubMed] 
143. Munson, M.A.; Nedwell, D.B.; Embley, T.M. Phylogenetic diversity of Archaea in sediment samples from a coastal salt marsh. Appl. Environ. Microbiol. 1997, 63, 4729-4733. [PubMed]

144. Lavens, P.; Sorgeloos, P. The history, present status and prospects of the availability of Artemia cysts for aquaculture. Aquaculture 2000, 181, 397-403. [CrossRef]

145. Kellogg, C.A.; Griffin, D.W. Aerobiology and the global transport of desert dust. Trends Ecol. Evol. 2006, 21, 638-644. [CrossRef] [PubMed]

146. Hirst, J.M.; Stedman, O.J.; Hurst, G.W. Long-distance spore transport: Vertical sections of spore clouds over the sea. J. Gen. Microbiol. 1957, 48, 357-377. [CrossRef] [PubMed]

147. Echigo, A.; Hino, M.; Fukushima, T.; Mizuki, T.; Kamekura, M.; Usami, R. Endospores of halophilic bacteria of the family Bacillaceae isolated from non-saline Japanese soil may be transported by Kosa event (Asian dust storm). Saline Syst. 2005, 1, 8. [CrossRef] [PubMed]

148. Duce, R.A.; Unni, C.K.; Ray, B.J.; Prospero, J.M.; Merrill, J.T. Long-range atmospheric transport of soil dust from Asia to the tropical north Pacific: Temporal variability. Science 1980, 209, 1522-1524. [CrossRef] [PubMed]

149. Taylor, D.A. Dust in the wind. Environ. Health Perspect. 2002, 110, A80. [CrossRef] [PubMed]

150. Fendrihan, S.; Berces, A.; Lammer, H.; Musso, M.; Ronto, G.; Polacsek, T.K.; Holzinger, A.; Kolb, C.; Stan-Lotter, H. Investigating the effects of simulated Martian ultraviolet radiation on Halococcus dombrowskii and other extremely halophilic Archaebacteria. Astrobiology 2009, 9, 104-112. [CrossRef] [PubMed]

151. Stan-Lotter, H.; Fendrihan, S. Halophilic archaea: Life with desiccation, radiation and oligotrophy over geological times. Life 2015, 5, 1487-1496. [CrossRef] [PubMed]

152. Alerstam, T. Bird Migration; Cambridge University Press: Cambridge, UK, 1993; ISBN 0521448220.

153. Liechti, F.; Schaller, E. The use of low-level jets by migrating birds. Naturwissenschaften 1999, 86, 549-551. [CrossRef] [PubMed]

154. Able, K.P. A radar study of the altitude of nocturnal passerine migration. Bird Band. 1970, 41, $282-290$. [CrossRef]

(C) 2018 by the authors. Licensee MDPI, Basel, Switzerland. This article is an open access article distributed under the terms and conditions of the Creative Commons Attribution (CC BY) license (http:/ / creativecommons.org/licenses/by/4.0/). 